\title{
How will organic carbon stocks in mineral soils evolve under future climate? Global projections using RothC for a range of climate change scenarios
}

\author{
P. Gottschalk ${ }^{1,2}$, J.U. Smith ${ }^{1}$, M. Wattenbach ${ }^{1,3}$, J. Bellarby ${ }^{1}$, E. Stehfest ${ }^{4}$, N. Arnell ${ }^{5}$, T. J. Osborn ${ }^{6}$, C. Jones ${ }^{7}$, and \\ P. Smith ${ }^{1}$ \\ ${ }^{1}$ University of Aberdeen, Institute of Biological and Environmental Sciences, School of Biological Sciences, 23 St Machar \\ Drive, Aberdeen, AB24 3UU, UK \\ ${ }^{2}$ Potsdam Institute for Climate Impact Research, Telegrafenberg, 14473 Potsdam, Germany \\ ${ }^{3}$ German Research Centre for Geosciences, Telegrafenberg, 14473 Potsdam, Germany \\ ${ }^{4}$ Netherlands Environmental Assessment Agency, Antonie van Leeuwenhoeklaan 9, 3721 MA Bilthoven, The Netherlands \\ ${ }^{5}$ Walker Institute for Climate System Research, University of Reading, Earley Gate, Reading, UK \\ ${ }^{6}$ Climatic Research Unit, School of Environmental Sciences, University of East Anglia, Norwich, RG6 6AR, UK \\ ${ }^{7}$ Hadley Centre, Met Office, Exeter, EX1 3PB, NR4 7TJ, UK \\ Correspondence to: P. Gottschalk (pia.gottschalk@pik-potsdam.de)
}

Received: 15 November 2011 - Published in Biogeosciences Discuss.: 13 January 2012

Revised: 23 June 2012 - Accepted: 25 June 2012 - Published: 14 August 2012

\begin{abstract}
We use a soil carbon (C) model (RothC), driven by a range of climate models for a range of climate scenarios to examine the impacts of future climate on global soil organic carbon (SOC) stocks. The results suggest an overall global increase in SOC stocks by 2100 under all scenarios, but with a different extent of increase among the climate model and emissions scenarios. The impacts of projected land use changes are also simulated, but have relatively minor impacts at the global scale. Whether soils gain or lose SOC depends upon the balance between $\mathrm{C}$ inputs and decomposition. Changes in net primary production (NPP) change $\mathrm{C}$ inputs to the soil, whilst decomposition usually increases under warmer temperatures, but can also be slowed by decreased soil moisture. Underlying the global trend of increasing SOC under future climate is a complex pattern of regional SOC change. SOC losses are projected to occur in northern latitudes where higher SOC decomposition rates due to higher temperatures are not balanced by increased NPP, whereas in tropical regions, NPP increases override losses due to higher SOC decomposition. The spatial heterogeneity in the response of SOC to changing climate shows how delicately balanced the competing gain and loss processes are, with subtle changes in temperature, moisture, soil
\end{abstract}

type and land use, interacting to determine whether SOC increases or decreases in the future. Our results suggest that we should stop looking for a single answer regarding whether SOC stocks will increase or decrease under future climate, since there is no single answer. Instead, we should focus on improving our prediction of the factors that determine the size and direction of change, and the land management practices that can be implemented to protect and enhance SOC stocks.

\section{Introduction}

Soils contain the largest pool of the terrestrial carbon (C). However, in the past, human-induced land use change has caused a significant loss of soil organic carbon (SOC) with global estimates ranging between $40-537 \mathrm{Pg} \mathrm{C}$ (Lal, 2003). However, due to its large size and long residence time, SOC can act as a large sink of atmospheric C (Post et al., 1982; Smith, 2004; Lal, 2004). It has been shown that the temperature sensitivity of the global SOC pool has a significant effect on the development of the future climate (Cox et al., 2000;Dufresne et al., 2002; Friedlingstein et al., 2003).

Published by Copernicus Publications on behalf of the European Geosciences Union. 
However, the magnitude of this effect is still highly uncertain (Friedlingstein et al., 2006), and the question of whether, and for how long, soils will act as a source or sink of atmospheric $\mathrm{CO}_{2}$, remains open (Smith et al., 2008).

Soil organic carbon dynamics are driven by changes in climate and land cover or land use. In natural ecosystems, the balance of SOC is determined by the gains through plant and other organic inputs and losses due to the turnover of organic matter (Smith et al., 2008). It is predicted that plant inputs, through increases in net primary production (NPP), will increase globally in the future due to the longer growing seasons in cooler regions and the fertilisation effect of $\mathrm{CO}_{2}$, but at the same time SOC turnover will be enhanced by increasing temperature. Whether SOC stocks increase or decrease under climate change depends upon which process dominates in the future at a given location, and whether increased plant inputs can outweigh increased turnover. Each process may have a different sensitivity to climate change (Fang et al., 2005; Knorr et al., 2005; Davidson and Janssens, 2006; Eglin et al., 2010).

Mechanistic models of SOC integrate the different drivers to calculate their combined impact on SOC dynamics. In the past decade, a number of modelling studies have investigated the global response of terrestrial $\mathrm{C}$ pools to changes in future climate and atmospheric $\mathrm{CO}_{2}$ concentrations. In these studies different terrestrial ecosystem models were applied in conjunction with climate change projected by different GCMs and different anthropogenic $\mathrm{CO}_{2}$ emission scenarios (Cramer et al., 2001; Ito, 2005; Berthelot et al., 2005; Lucht et al., 2006; Jones et al., 2005). Cramer et al. (2001) and Jones et al. (2005) used different terrestrial biophysical models driven by one climate change scenario to study the effect of climate change on terrestrial C. SOC stocks, simulated under dynamic potential natural vegetation cover, showed a consistent positive trend across six dynamic global vegetation models (DGVM) with a mean increase of ca. $110 \mathrm{Pg} \mathrm{C}$ in the $21 \mathrm{st}$ century (Cramer et al., 2001) under the IS92a IPCC emission scenario driving the Hadley Centre atmosphere-ocean global circulation model (AOGCM) HadCM2-SUL. However, the study of Jones et al. (2005) projects a steady increase in SOC stocks until about 2050 and thereafter a sharp decline, ending with an overall decrease of SOC between 84 and $110 \mathrm{PgC}$ in 2100 , compared to 2000 SOC levels. While Jones et al. (2005) uses only a later version of the Hadley Centre AOGCM, namely HadCM3LC, the response of the two different SOC modules is different to the six DGVMs in the study of Cramer et al. (2001).

Ito (2005) used the terrestrial ecosystem Sim-CYCLE model to study the impact of seven climate scenarios generated by different AOGCMs under the SRES A2 emission scenario and further the impact of seven SRES scenarios interpreted by the AOGCM CCSR/NIES model (Japan) on the terrestrial $\mathrm{C}$ budget. He found variable responses between the different AOGCM simulations on the global SOC stock. The total range was $252 \mathrm{Pg} \mathrm{C}$, ranging from an increase of
$+102 \mathrm{PgC}$ to a decrease of $-150 \mathrm{PgC}$ in the 21 st century. The variability between the SRES simulations was only 119 $\mathrm{PgC}$, ranging from a loss of 68 to $187 \mathrm{Pg} \mathrm{C}$ in the 21st century. Lucht et al. (2006) reported an increase of global SOC stocks between +80 and $+97 \mathrm{PgC}$ when using the LundPotsdam-Jena Model (LPJ) driven by the AOGCMs Echam5 and HadCM3, which interprets the SRES B1 and SRES A2 emission scenarios, respectively.

While Cramer et al. (2001), Jones et al. (2005), Lucht et al. (2006), and Ito (2005) simulate future C pool changes under potential natural vegetation, they focus on physiological responses and do not consider the effect of actual land use distribution or changes in anthropogenic land use. Furthermore, Sim-CYCLE implements a single soil C pool module to simulate SOC dynamics (Ito, 2005). However, Jones et al. (2005) have shown that such a simplification leads to an overall higher sensitivity of SOC to changes in climate and plant inputs than a multi-pool SOC model, where the first might overestimate the SOC response to environmental changes. Jones et al. (2005) used RothC in an off-line study to compare the decomposition sensitivity of the multi-pool soil C model to the built-in, one-pool SOC turnover model of the HadCM3LC model. To compare the simulation results, RothC was driven by climate fields of the HadCM3LC model. It showed a slower response in decomposition rate of SOC to climate change when compared to the single pool soil $\mathrm{C}$ model, although the overall trajectory of the response was similar. A steady increase in total global SOC stocks (i.e. C sink) became negative by 2060 .

The studies described above were carried out in "off-line" mode, which means that feedback loops of the terrestrial C fluxes into the atmosphere, constituting a possible positive feedback for climate change, were not accounted for. Several studies have speculated on the "positiveness" of this feedback loop using climate models, which are interactively coupled with C-cycle models (Cox et al., 2000; Dufresne et al., 2002; Friedlingstein et al., 2006). A unanimous conclusion is that the sensitivity of soil respiration to temperature in the model implementation dominates the magnitude of the overall terrestrial $\mathrm{C}$ climate feedback, emphasising the need for a better quantification of soil $\mathrm{C}$ responses to climate change (Fang et al., 2005; Knorr et al., 2005; Davidson and Janssens, 2006; Smith et al., 2008). The sources of uncertainty in coupled C-cycle and climate models lead to a wide range of possible futures and in turn different developments of SOC stocks.

In this study, we use a dedicated, multi-pool SOC model (RothC) in off-line mode to further examine likely responses to future climate considering actual current land use and interactions with projected future land use change (LUC). The RothC model (Coleman and Jenkinson, 1996) is one of the most widely used SOC models (e.g. Jenkinson et al., 1991; McGill, 1996). This model has been satisfactorily evaluated against data from long-term experiments across a comprehensive combination of ecosystems and climate conditions 
(Coleman et al., 1997; Diels et al., 2004; Kamoni et al., 2007; Shirato et al., 2005; Falloon and Smith, 2002), including arid environments (Jenkinson et al., 1999; Skjemstad et al., 2004) and land use change (Cerri et al., 2003; Smith et al., 1997). It has been used to make regional- and global-scale predictions in a variety of studies (Wang and Polglase, 1995; Falloon et al., 1998; Tate et al., 2000; Falloon and Smith, 2002; Smith et al., 2005; Smith et al., 2007). Here we use the RothC model to investigate how climate change predictions affect the possible futures of SOC. Due to extensive previous benchmarking (see details of given references), no further model testing is presented here.

In this study, the model was run at a spatial resolution of $0.5 \times 0.5$ degree with different sets of climate scenarios. These sets of climate scenarios describe within-AOGCM variability using the SRES A1b $\mathrm{CO}_{2}$-emission scenario to drive the AOGCMs as well as within-SRES variability using one AOGCM - namely HadCM3 interpreting four SRES scenarios: A1b, A2, B1 and B2. The different SRES scenarios also incorporate different LUC trajectories. A further study was carried out to quantify the contribution of LUC and NPP change separately on the change in SOC.

The objectives of this paper are (a) to define possible future developments of global SOC stocks, (b) to assess the contribution of LUC to future changes in SOC, (c) to assess regional developments of SOC, and (d) to evaluate the differences in projected SOC arising from (i) the use of several AOGCMs interpreting one SRES scenario, and (ii) the use of one AOGCMs interpreting different SRES scenarios.

\section{Methods and data}

\subsection{The RothC model}

The RothC model includes five pools of SOM: DPM (decomposable plant material), RPM (resistant plant material), BIO (microbial biomass), HUM (humified OM) and IOM (inert OM). All pools, apart from IOM, decompose by first-order kinetics and use a rate constant specific to each pool. Pools decompose into $\mathrm{CO}_{2}, \mathrm{BIO}$ and $\mathrm{HUM}$. The proportion of $\mathrm{BIO}$ to $\mathrm{HUM}$ is a fixed parameter, whereas the proportion of $\mathrm{CO}_{2}$ to $\mathrm{BIO}+\mathrm{HUM}$ varies according to the clay content. Less clay leads to a relatively higher loss of $\mathrm{CO}_{2}$. Further, decomposition is sensitive to temperature and soil moisture. Hence, soil texture, monthly climate, land use and cultivation data are the inputs to the model (Coleman and Jenkinson, 1996; Smith et al., 1997). Three land use types are parameterized in RothC by default: arable, grassland and forest. They differ in terms of plant input quality and the time distribution of plant inputs over the year. Plant quality determines the proportions of plant input that enter the DPM and RPM pool. The specific ratios of DPM/RPM are 1.44 for arable, 0.67 for grassland and 0.25 for forest. A lower ratio signifies greater decomposability with more plant material entering the DPM
Table 1. Distribution of plant $\mathrm{C}$ inputs into the soil expressed as a proportion of the total.

\begin{tabular}{lrrr}
\hline Month/land use & Arable & Grassland & Forest \\
\hline January & 0.0 & 0.05 & 0.025 \\
February & 0.0 & 0.05 & 0.025 \\
March & 0.0 & 0.05 & 0.025 \\
April & 0.16667 & 0.05 & 0.025 \\
May & 0.16667 & 0.1 & 0.05 \\
June & 0.16667 & 0.15 & 0.05 \\
July & 0.5 & 0.15 & 0.05 \\
August & 0.0 & 0.10 & 0.05 \\
September & 0.0 & 0.10 & 0.20 \\
October & 0.0 & 0.10 & 0.20 \\
November & 0.0 & 0.05 & 0.20 \\
December & 0.0 & 0.05 & 0.1 \\
\hline
\end{tabular}

pool (fast turnover) and less entering the RPM pool (slow turnover). A higher ratio signifies the opposite. The distribution of plant inputs throughout the year for the three land use types mimics the dynamics of typical crop rotations and of permanent grassland or forest in Europe (Table 1). Over long time periods, the model is insensitive to the distribution of plant inputs throughout the year (Smith et al., 2005), so the distribution of inputs used for Europe was applied globally. The total yearly input of $\mathrm{C}$ from plants, however, is an essential driver of SOC dynamics.

\subsection{Climate data and scenarios (1901-2100)}

Observed and predicted climate data are given on a monthly temporal, and 0.5 degree spatial resolution. From 1901 to 2005, observed climate data from CRU TS 3.0 were used. Scenario data spanned 2006 to 2100. The climate data were provided within the QUEST-GSI project and are available online (http://www.cru.uea.ac.uk/ timo/climgen/data/ questgsi/).

Two sets of climate data from seven AOGCMs and four SRES scenarios were used in this study. One set encompasses the different interpretations of the SRES A1b emission scenario by seven AOGCMs (CCCMA-CGCM3.1(T47), CSIRO-MK3.0, IPSL-CM4, MPI-ECHAM5, NCARCCSM3.0, UKMO-HadCM3 and UKMO-HadGEM1), representing a cross-section of possible results for the climate change scenario (Table 2). The second set of climate data comprises four different SRES scenarios, interpreted using a single AOGCM (UK-model HadCM3); outputs are obtained for the four SRES scenarios A1b, A2, B1 and B2. 
Table 2. Overview of GCMs used in this study.

\begin{tabular}{ll}
\hline Models & References \\
\hline CCCMA-CGCM3.1(T47) & McFarlane et al. (2005), Scinocca et al. (2008) \\
CSIRO-MK3.0 & Gordon et al. (2002) \\
IPSL-CM4 & Hourdin et al. (2006) \\
MPI-ECHAM5 & Giorgetta et al. (2006) \\
NCAR-CCSM3.0 & Collins et al. (2006) \\
UKMO-HadCM3 & Gordon et al. (2000) \\
UKMO-HadGEM1 & Johns et al. (2006) \\
\hline
\end{tabular}

\subsection{Soil data}

Mean SOC stocks in $0 \mathrm{~cm}$ to $30 \mathrm{~cm}$ depth and the percentage of clay are derived from the ISRIC-WISE global data set of derived soil properties (Version 3.0) on a 0.5 by 0.5 degree grid (Batjes, 2005). This data set interpolates soil characteristics of individual soil profile measurements from around the globe. These profile measurements were mainly taken in the decades of 1970 to 1990 . Therefore, the SOC values used in this study represent the soil state roughly at the end of the last century. In this data set, each grid cell is covered by up to ten dominant soil types and gives their respective coverage in $\%$. Each of these soil types was simulated consecutively in conjunction with the same input data within one scenario simulation. Results were aggregated over the different soil types per grid cell on an area-weighted basis. Since RothC is neither parameterised, nor recommended for use on organic soils, soils with SOC content higher than $200 \mathrm{~cm}$ (Smith et al., 2005) were omitted from the simulations.

\subsection{Land use \& land use change data}

Gridded land use data as simulated by the Integrated Model to Assess the Environment (IMAGE) version 2.4 (MNP, 2006) were used in the RothC simulations. LUC in IMAGE is driven by (agro-)economic and climatic factors, such as changes in the demand for feed and food and the potential vegetation (MNP, 2006). IMAGE-data were available from 1970 onwards and we therefore also use 1970 as the start date for our simulations. Figure 1 shows the regional distribution of LUC between 1970 and 2100 exemplarily for the A1b scenario as deviations of LUC patterns among emission scenarios are small.

IMAGE simulates 20 land cover classes. These classes were classified into the three land use types which are implemented in RothC: arable, grassland and forestry. The classification is shown in Table 3 .

IMAGE simulations have the same spatial resolution of 0.5 degree as the climate data used in this study and each grid cell is considered to be homogeneous in terms of land
Table 3. Classification of IMAGE land use types into RothC land cover classes. “-9999” denotes areas which were not simulated.

\begin{tabular}{ll}
\hline Land use (IMAGE 2.4) & $\begin{array}{l}\text { New Corresponding } \\
\text { RothC land use code }\end{array}$ \\
\hline Agricultural land & 1 - arable \\
Extensive grassland & 2 - grassland \\
C plantations (not used) & No cells \\
Regrowth forest (Abandoning) & 3 - forest \\
Regrowth forest (Timber) & 3 - forest \\
Biofuel & $1-$ arable \\
Ice & -9999 \\
Tundra & $2-$ grassland \\
Wooded tundra & $2-$ grassland \\
Boreal forest & $3-$ forest \\
Cool conifer & $3-$ forest \\
Temperate mixed forest & 3 - forest \\
Temperate deciduous forest & $3-$ forest \\
Warm mixed forest & $3-$ forest \\
Grassland/steppe & $2-$ grassland \\
Hot desert & -9999 \\
Scrubland & $2-$ grassland \\
Savannah & $2-$ grassland \\
Tropical woodland & $3-$ forest \\
Tropical forest & $3-$ forest \\
\hline
\end{tabular}

use, LUC and NPP. Land use change patterns are given in 5 -year time intervals.

\subsection{Changes in soil carbon inputs according to changes in NPP}

Simulating changes in global SOC stocks under different climate scenarios requires realistic estimates of changes in plant inputs to the soil under the different climate projections. However, total plant $\mathrm{C}$ inputs to the soil, which include plant litter, root exudates and fine root turnover, are rarely known. To overcome this problem, RothC is run in reverse mode to calculate initial plant inputs to the soil for 


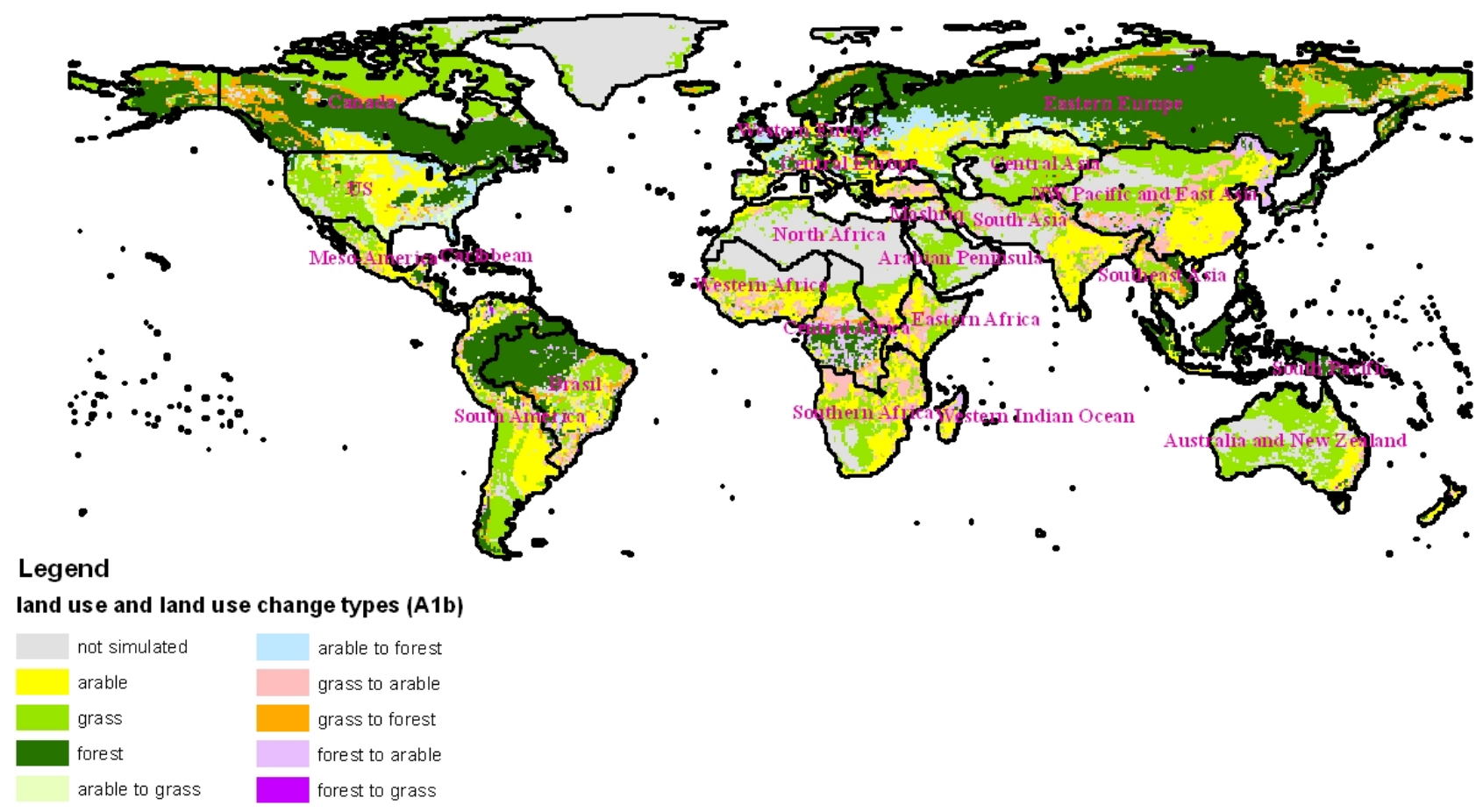

Fig. 1. Areas under the A1b scenario that are continuously covered by arable, grassland and forest from 1971 to 2100 . Land use type changes from 1971 to 2100 are depicted, neglecting intermediate changes. Note that the distributions of land use and land use change under SRES B1, A2, and B2 are very similar and are not plotted separately. Relevant differences are noted in the text.

the given environmental conditions. Once the plant inputs have been established in this way, the year-to-year changes are adjusted according to the year-to-year changes in NPP, because changes in $\mathrm{C}$ inputs to the soil can be associated with changes in NPP (Smith et al., 2005). Using the same approach as in Smith et al. (2005), we calculated changes in soil carbon inputs based on the changes in NPP data simulated by the IMAGE model version 2.4 (MNP, 2006). This scaling is appropriate as IMAGE-NPP also reflects changes in land cover change (see Sect. 2.4). Since land use change (amongst other factors) influences NPP changes in IMAGE, RothC uses these two drivers in a consistent way. The details of the simulation setup of this approach are described in the section "Simulation procedure".

IMAGE NPP is a function of air temperature, soil moisture status, $\mathrm{CO}_{2}$-fertilisation, land cover and land cover history, nutrient availability, species characteristics and altitude (MNP, 2006). The carbon cycle model implemented in IMAGE is thoroughly described in Klein Goldewijk et al. (1994) and has been successfully evaluated (Alcamo et al., 1994) and applied (Van Minnen et al., 2000, 2009) globally. Further, IMAGE NPP compares well with NPP results of the $\mathrm{C}^{4}$ MIP study (Friedlingstein et al., 2006) in which dynamic global vegetation models coupled with AOGCMs were used to calculate (among others) NPP for the SRES A2 scenario. IMAGE NPP values of the SRES A2 scenario represent a medium scenario among the $\mathrm{C}^{4}$ MIP scenarios for all global zones (Fig. 2). IMAGE NPP data are again given in 5-year time intervals and are subsequently linearly interpolated for our study to yearly values between 1971-2100.

NPP surfaces to scale plant input values were only available for the four SRES scenarios A1b, A2, B1 and B2, simulated by the IMAGE 2.4 model. To scale NPP values for the different temperature and precipitation trends of the seven AOGCM realisations of A1b, we associated the IMAGE A1b NPP surface with the temperature and precipitation predictions of HadCM3, and scaled this baseline NPP surface according to the difference between the temperature and precipitation predictions from the other six AOGCMs and HadCM3, using the MIAMI-NPP model (Lieth, 1972). The MIAMI model links long-term average temperature and precipitation data with NPP via two simple regression functions (Lieth, 1972, 1975) derived from global NPP data sets, and has been applied globally to simulate NPP (e.g. Zheng et al., 2003).

The equations of the MIAMI-model are given by

$\mathrm{NPP}=\min \left(\mathrm{NPP}_{T}, \mathrm{NPP}_{P}\right)$

with

$$
\begin{aligned}
& \mathrm{NPP}_{T}=3000 \cdot(1+\exp (1.315-0.119 \cdot \bar{T})) \\
& \mathrm{NPP}_{P}=3000 \cdot(1-\exp (-0.000664-0.119 \cdot \bar{P}))
\end{aligned}
$$

where NPP is the climatic net primary production (in g) dry matter (DM) $\mathrm{m}^{-2} \mathrm{yr}^{-1}, \mathrm{NPP}_{T}$ is the temperature dependency 


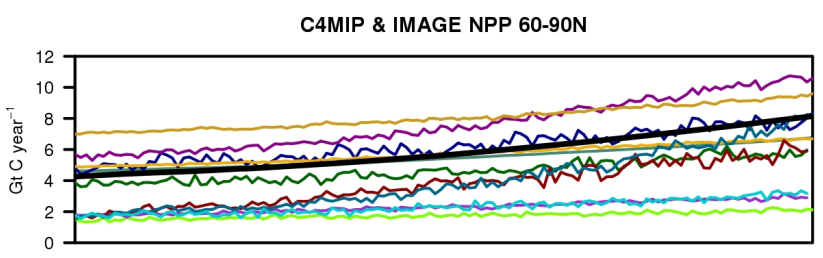

C4MIP \& IMAGE NPP 30-60N

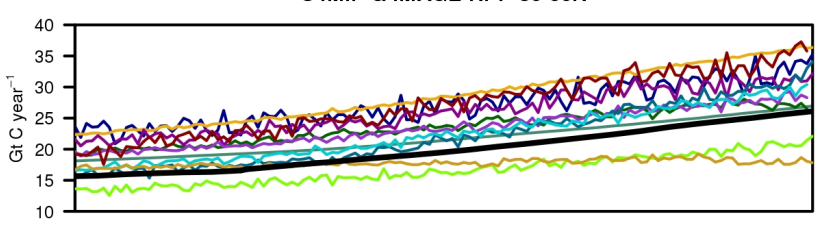

C4MIP \& IMAGE NPP Eq-30N

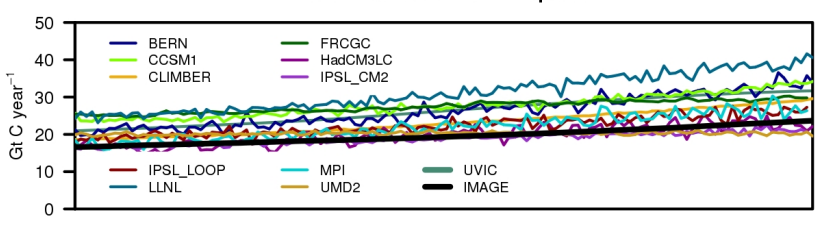

C4MIP \& IMAGE NPP 30S-Eq

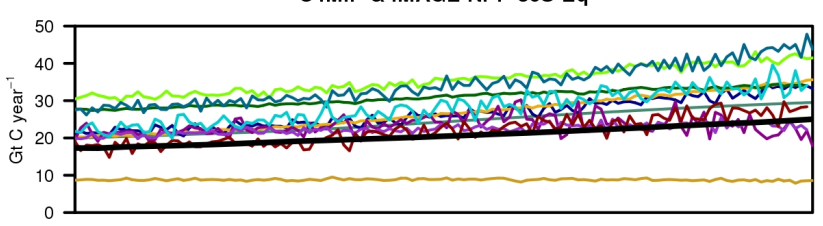

C4MIP \& IMAGE NPP 90-30S

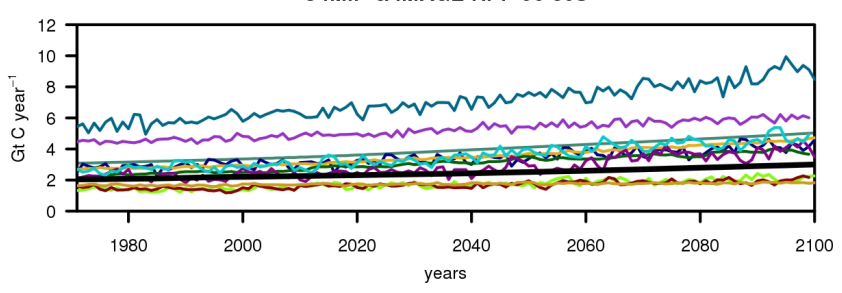

Fig. 2. Comparison of zonal NPP of IMAGE and $\mathrm{C}_{4} \mathrm{MIP}-$ simulations (Friedlingstein et al., 2006) for the SRES A2 emission scenario. Please refer to respective study for details on model abbreviations.

term of NPP with $\bar{T}$ being annual mean temperature $\left({ }^{\circ} \mathrm{C}\right)$ and $\mathrm{NPP}_{P}$ is the moisture dependency term of NPP with $\bar{P}$ being the mean annual sum of precipitation (mm). NPP is either limited by temperature or precipitation, but this model does not account for the limiting effects when temperature or precipitation is too high. The maximum NPP that can be reached is limited to $3000 \mathrm{~g} \mathrm{DM} \mathrm{m}^{-2} \mathrm{yr}^{-1}$. Absolute NPP values derived from MIAMI were not used directly, but were only used to scale IMAGE baseline NPP estimates.
IMAGE baseline NPP values were adjusted by the percentage change, calculated by the MIAMI-NPP model, between the baseline temperature/precipitation of HadCM3 and temperature/precipitation simulated by the other AOGCMs within each 0.5 degree global grid cell and each year.

The following equation was used to scale NPP from the baseline IMAGE associated with HadCM3, to the NPP of the other six AOGCMs:

$\mathrm{NPP}_{\text {AOGCMx }}=\mathrm{NPP}_{\text {IMAGE_Alb }}$
$+\left(\mathrm{NPP}_{\text {IMAGE_Alb }} \cdot \frac{\mathrm{NPP}_{\text {MIAMI_AOGCMx }}-\mathrm{NPP}_{\text {MIAMI_HadCM3 }}}{\text { NPP }_{\text {MIAMI_HadCM3 }}}\right)$

where $\mathrm{NPP}_{\mathrm{AOGCMx}}$ is the AOGCM-specific NPP value with $\mathrm{x}=1 \ldots 6, \mathrm{NPP}_{\text {IMAGE }} \mathrm{A} 1 \mathrm{~b}$ is the NPP value of the IMAGE baseline (here A1b) scenario, NPPMIAMI_HadCM3 is the NPP value calculated by the MIAMI model with the temperature of the AOGCM reference scenario (here HadCM3) and NPPMIAMI_AOGCMx is the NPP value calculated by the MIAMI model with the temperature of the particular AOGCM scenario. A graphic example of the scaling approach for an arbitrary grid cell is given in Fig. 3 .

\subsection{Simulation procedure}

The RothC model has previously been adapted to run with large spatial data sets and to use potential evapotranspiration (PET) in place of open pan evaporation (Smith et al., 2005). Since the modelling procedure is similar to that of Smith et al. (2005, 2006), only a brief description is given here. In the first initialisation step, RothC is run iteratively to equilibrium to calculate the sizes of the SOC pools and annual plant inputs using long-term average climate data (Coleman and Jenkinson, 1996) from 1901 to 1970. The model calculates the soil pools and required $\mathrm{C}$ inputs according to the climate, land use, clay and SOC for 1970. In the forward run, from 1971 to 2100 , climate, land use and $\mathrm{C}$ input changes determine SOC changes. $\mathrm{C}$ inputs are adjusted following the approach described in Smith et al. (2005):

$\mathrm{PI}_{t}=\mathrm{PI}_{t-1} \cdot \frac{\mathrm{NPP}_{t}}{\mathrm{NPP}_{t-1}}$

where $\mathrm{PI}_{t}$ is the plant $\mathrm{C}$ input in the given year $\left(\mathrm{tCha}^{-1}\right.$ $\left.\mathrm{yr}^{-1}\right), \mathrm{PI}_{t-1}$ is the plant $\mathrm{C}$ input in the previous year $\left(\mathrm{tC} \mathrm{ha}^{-1}\right.$ $\left.\mathrm{yr}^{-1}\right), \mathrm{NPP}_{t}$ is the NPP value for the given year $\left(\mathrm{tCha}^{-1}\right.$ $\mathrm{yr}^{-1}$ ) and NPP $\mathrm{N}_{t-1}$ is the NPP value of the previous year $\left(\mathrm{tCha}^{-1} \mathrm{yr}^{-1}\right)$. Smith et al. (2005) note that it is uncertain whether $\mathrm{C}$ input to the soil changes proportionally with changes in NPP, and that the influence of NPP established here should be regarded as the maximum possible.

Changes in land use are simulated stepwise in 5-yr intervals. The change from one land use type to the next is mainly reflected by the change in the DPM/RPM ratio of the model, accompanied by a change in the amount of plant inputs according to the NPP change. A total of 10 global simulations 

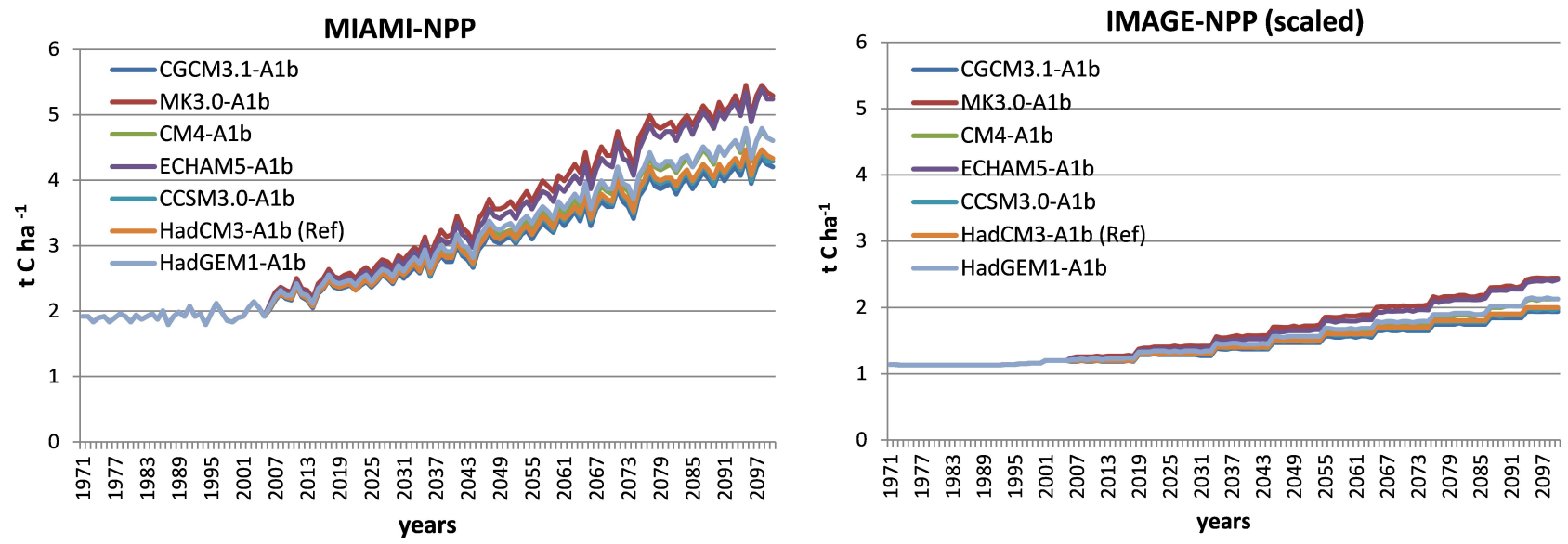

Fig. 3. Example of the NPP-scaling approach for an arbitrary grid cell. The panel on the left depicts NPP values calculated based on mean yearly temperature and precipitation for the seven AOGCMs. The panel on the right shows the correspondingly scaled IMAGE-NPP values with HadCM3 being associated with the IMAGE-A1b-NPP surface.

(a)

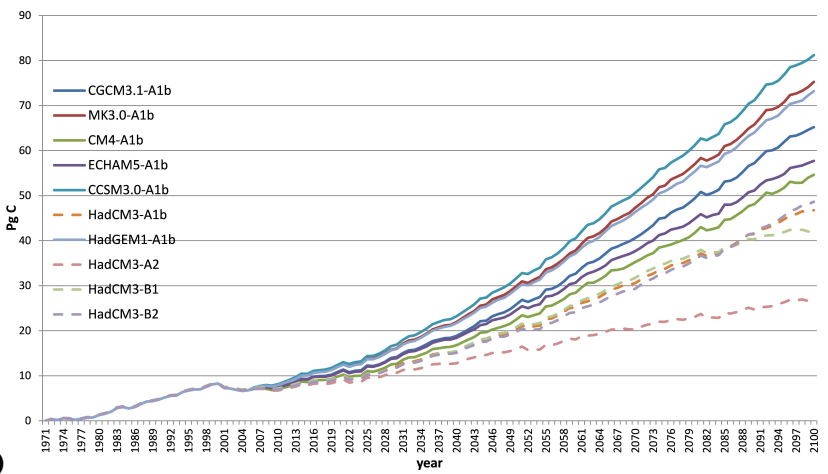

(c)

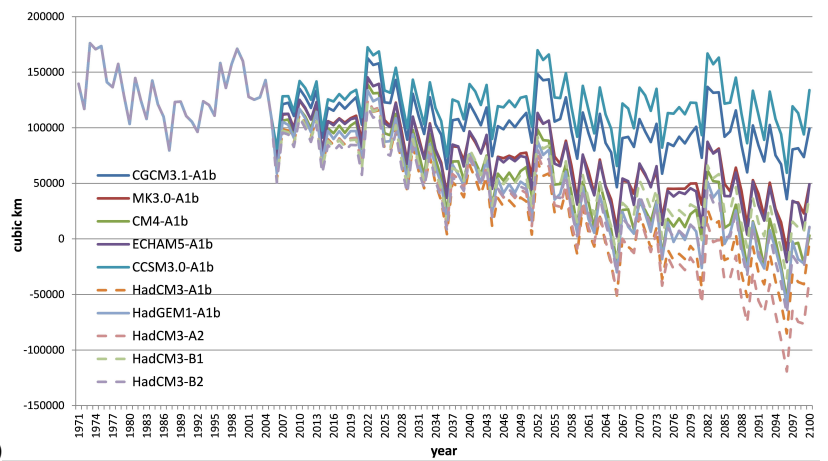

(b)

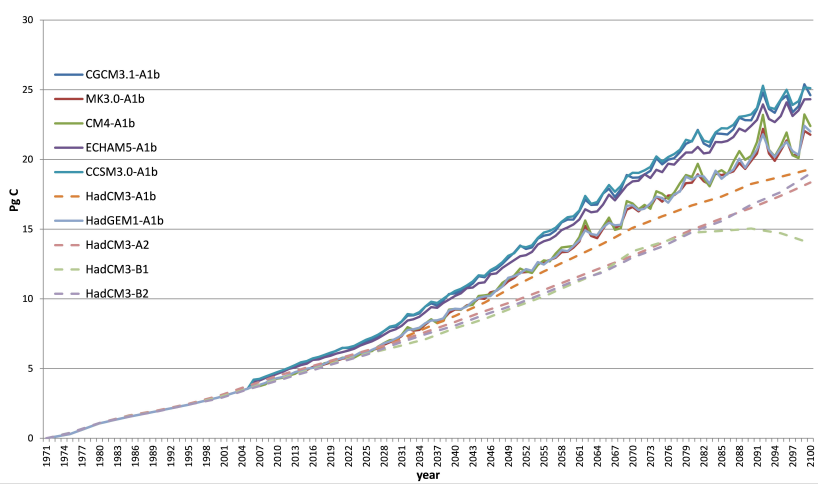

(d)

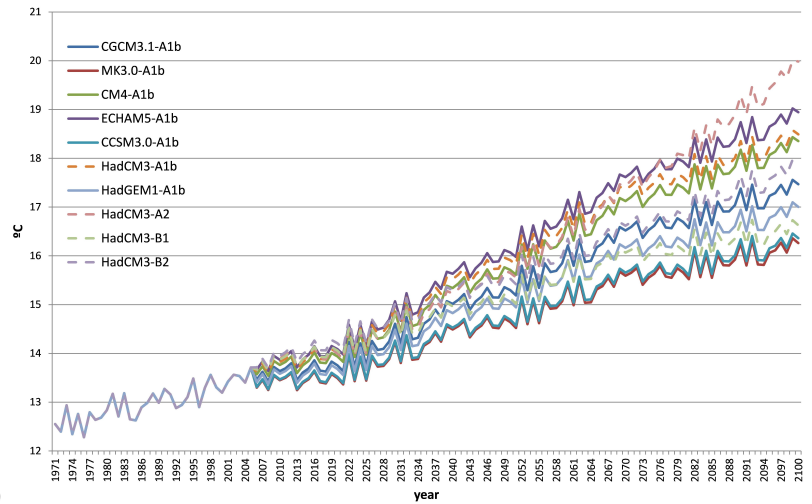

Fig. 4. (a) Total global changes in mineral SOC for ten climate scenarios, (b) changes in global plant inputs for ten climate scenarios, (c) changes in the global climatic water balance (i.e. precipitation minus evapotranspiration), (d) global mean surface temperature. All panels show results only from simulated land cells for which consistent data were available and which have a SOC concentration lower than $200 \mathrm{tha}^{-1}$ 
were carried out including the effect of climate, land use and NPP change (default simulations).

\subsection{Contribution of land use change to SOC stock changes}

To examine the different influence of land use and NPP change on SOC, the HadCM3 model, in conjunction with SRES A1b, was run under three additional different set-ups: (a) simulation including the effect of LUC but keeping NPP constant over time, (b) simulation including the effect of NPP change but keeping the land use constant over time, and (c) simulation including neither change in NPP nor land use. The results of these additional simulations were then compared to the HadCM3 + SRES A1b simulation including both LUC and NPP change, which is the default set-up for all the other simulations (Sect. 2.6).

As previously stated, NPP and LUC are interlinked. NPP simulated by IMAGE differs not only according to temperature and precipitation change, but also according to LUC. Therefore, to simulate the effect of NPP alone without LUC, the NPP scaling based on IMAGE NPP cannot be used. Instead, plant inputs were scaled according to the NPP change based on the calculation of MIAMI-NPP change. Simulation $\mathrm{b}$ follows this protocol. $\mathrm{CO}_{2}$-fertilisation is accounted for, as although MIAMI-NPP changes do not account for the $\mathrm{CO}_{2}$ fertilisation effect, MIAMI-NPP values are only used to scale IMAGE-NPP outputs, which do include $\mathrm{CO}_{2}$-fertilisation.

\section{Results and discussion}

\subsection{Global mineral soil organic carbon dynamics}

The initial sum of mineral SOC simulated in the first $30 \mathrm{~cm}$ of the soil amounts to ca. $502 \mathrm{Pg} \mathrm{C}$ in 1971. Global soils store $\sim 1550 \mathrm{Pg} \mathrm{C}$ (Lal, 2004) of which ca. $53 \%$ (global average) is distributed in the first $30 \mathrm{~cm}$ of the soil profile (Jobbagy and Jackson, 2000), which is 821.5 Pg C. The simulated value excludes all soils with a SOC density higher than $200 \mathrm{tha}^{-1}$ at the start and end of the simulation, i.e. all organic soils that contain 412 Pg to $1 \mathrm{~m}$ (Joosten, 2009), so the difference between the soil $\mathrm{C}$ accounted for is due to the exclusion of these soils.

Our simulations, including changes in climate, land use and NPP, suggest that aggregate global mineral SOC stocks continuously increase from 1971 up to 2100 with varying intensity in all scenarios except one, i.e. HadCM3-B1 (Fig. 4a). In the latter, SOC begins to level-out towards the end of this century. This steady increase over time is driven by increasing plant inputs projected by the IMAGE model (Fig. 4b) and a negative trend in the global climatic water balance (Fig. 4c), which reduces soil moisture, and will tend to slow organic matter decomposition. These two effects override the increase in decomposition rate arising from increased temperature (Fig. 4d).
Although SOC trends are consistently positive using the different AOGCMs and SRES scenarios, there is a considerable spread between the scenarios. Across all simulations, SOC increases between 26.4 and $81.2 \mathrm{Pg}$ SOC-C with a corresponding spread of $54.8 \mathrm{PgC}$. While SOC stocks increase between 46.8 to $81.2 \mathrm{Pg} \mathrm{C}$ within the seven AOGCMs ( spread $=34.5 \mathrm{Pg} \mathrm{C}$ ), the HadCM3 simulations driven by four SRES scenarios show a lower SOC stock gain from 26.4 to $48.6 \mathrm{Pg} \mathrm{C}$ ( $\operatorname{spread}=22.2 \mathrm{Pg} \mathrm{C})$. Figure $4 \mathrm{a}$ also shows that the SOC response to the HadCM3 climate scenario ranges at the lower end of all other AOGCMs responses, and therefore also the SRES realisations A2, B1 and B2 with HadCM3.

With a simulated consistent increase of global mineral SOC during the 21 st century, our results are generally in agreement with the works of Cramer et al. (2001), Friedlingstein et al. (2006), Ito (2005), Lucht et al. (2006), Müller et al. (2007) and Sitch et al. (2008), of which Friedlingstein et al. (2006) and Sitch et al. (2008) are coupled simulation studies. Our results are, however, in disagreement with Jones et al. (2005) and Schaphoff et al. (2006) (Table 4).

Absolute SOC stock changes cannot be directly compared as we are only considering the first $30 \mathrm{~cm}$ of the soil profile and the other studies consider total soil profiles (or to $1 \mathrm{~m}$ depth), and include areas covered by organic soils (although none treated organic soils differently to mineral soils), but percentage change can be compared. Cramer et al. (2001) use the IS92a anthropogenic emission scenario, which is comparable to the later IPCC A1b scenario in conjunction with the HadCM2-SUL version of the Hadley Centre AOGCM. Their simulations show a ca. $10 \%$ increase (mean of six DGVM) between 2000 and 2100, while our simulation of the A1b simulation driving the HadCM3 AOGCM results in a mean increase of ca. $8 \%$ of SOC stocks. Ito (2005) simulates, amongst others, SOC stock changes for the 21 st century using seven AOGCMs driven by the IPCC A2 scenario. Most AOGCMs are the same as those used in this study, but are earlier versions, and Ito (2005) simulated the A2 emissions scenario (lower climate forcing), whereas we largely used the Alb scenario (higher climate forcing). As expected, the percentage changes from Ito, 2005, are considerably smaller than the changes suggested in this study (Table 5).

However, in both studies, the AOGCMs rank similarly, with the climate from the NCAR model giving greatest SOC increase, and the climate as simulated by the Australian MK model giving the second highest increase. The simulation results using the Hadley Centre model climate forcing, both driven by the IPCC A2 emission scenario, give contradictory results; our results show a slight increase in SOC, whereas the study of Ito (2005) shows a decrease.

Lucht et al. (2006) simulated, amongst others, the SOC stock changes from 2000 to 2100 using the DGVM LPJmodel driven by climate fields of the ECHAM5 and HadCM3 models simulating the IPCC B1 and A2 emission scenarios, respectively. Changes in SOC amount to approximately $6 \%$ and $4.9 \%$ (Sybill Schaphoff, personal communication, 
Table 4. Literature compilation of global SOC trends and variability in 2100 compared to our study. Please refer to respective studies for details of the simulations and model abbreviations.

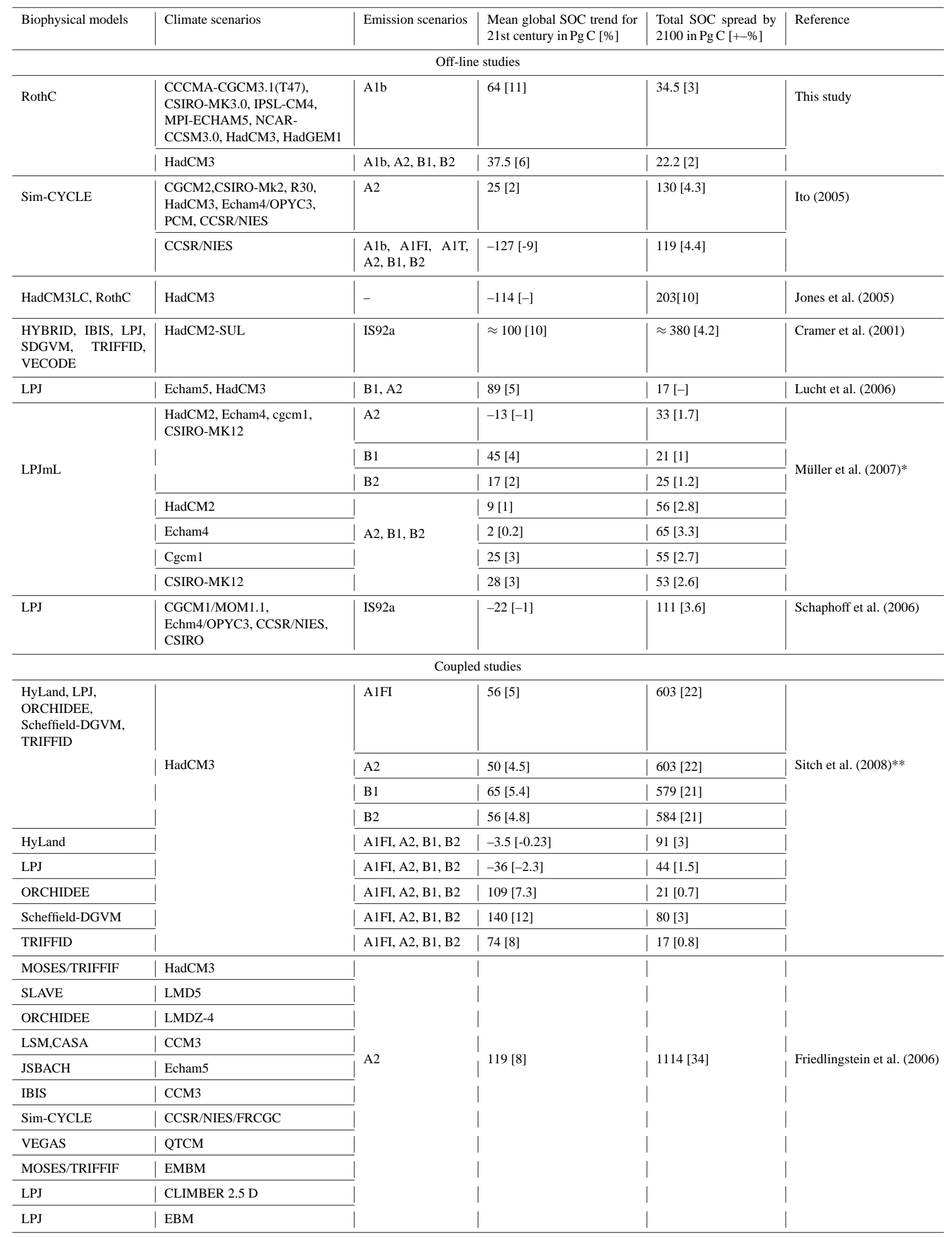

* Results from simulations which include changes in land use, atmospheric $\mathrm{CO}_{2}$ and climate.

** Data publicly available from: http://dgvm.ceh.ac.uk 
Table 5. Simulated changes of global SOC stocks in the 21 st century in $\%$ for the ten simulations of our study and the comparable studies of Ito (2005) and Müller et al. (2007). Please note that, except the simulations with the Hadley Centre AOGCM, the simulations differ in the driving anthropogenic emission scenario: A1b for our study and A2 for the study of Ito (2005) and A2, B1 and B2 for the study of Müller et al. (2007).

\begin{tabular}{|c|c|c|c|c|c|}
\hline \multicolumn{2}{|c|}{ This study } & \multicolumn{2}{|c|}{ Ito (2005) } & \multicolumn{2}{|c|}{ Müller et al. (2007) } \\
\hline Simulation & $\begin{array}{l}\text { Delta SOC } \\
2000-2100 \\
(\%)\end{array}$ & Simulation & $\begin{array}{l}\text { Delta SOC for } \\
\text { decades beginning in } \\
2000 \text { and } 2090(\%)\end{array}$ & Simulation & $\begin{array}{l}\text { Delta SOC for decades } \\
\text { beginning in } 1970 \text { and } \\
\text { 2091(\%) }\end{array}$ \\
\hline \multirow{3}{*}{ CGCM3.1-A1b } & \multirow{3}{*}{11.11} & \multirow{3}{*}{ CGCM2.0-A2 } & \multirow{3}{*}{ 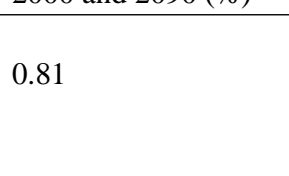 } & CGCM1 - A2 & -0.3 \\
\hline & & & & CGCM1 - B1 & 5.2 \\
\hline & & & & CGCM1 - B2 & 2.6 \\
\hline \multirow{3}{*}{ MK3.0-A1b } & \multirow{3}{*}{13.06} & \multirow{3}{*}{ MK2.0-A2 } & \multirow{3}{*}{1.69} & MK1.2 - A2 & 0.2 \\
\hline & & & & MK1.2 - A2 & 5.5 \\
\hline & & & & MK1.2 - A2 & 2.9 \\
\hline CM4-A1b & 9.04 & - & - & & \\
\hline \multirow{3}{*}{ ECHAM5-A1b } & \multirow{3}{*}{9.64} & \multirow{3}{*}{ ECHAM4-A2 } & \multirow{3}{*}{0.34} & ECHAM4-A2 & -3.1 \\
\hline & & & & ECHAM4-B1 & 3.4 \\
\hline & & & & ECHAM4-B2 & 0.4 \\
\hline CCSM3.0-A1b & 14.22 & $\begin{array}{l}\text { NCAR-PCM- } \\
\text { A2 }\end{array}$ & 6.96 & - & - \\
\hline HadGEM1-A1b & 12.66 & - & - & - & - \\
\hline HadCM3-A1b & 7.51 & - & - & - & - \\
\hline HadCM3-A2 & 3.5 & HadCM2-A2 & -1.89 & HadCM2 - A2 & -2 \\
\hline HadCM3-B1 & 6.51 & - & - & HadCM2 - B1 & 4 \\
\hline HadCM3-B2 & 7.86 & - & - & HadCM2 - B2 & 1 \\
\hline
\end{tabular}

2011), respectively, while our A2 simulations show a $3.5 \%$ increase. Results of the $\mathrm{C}^{4} \mathrm{MIP}$ study, in which 11 coupled climate-carbon-cycle models were forced by the A2 emission scenario (Friedlingstein et al., 2006), show a mean increase of global SOC of $8 \%$ compared to $3.5 \%$ in our HadCM3-A2 simulation.

Mean SOC stock trends predicted by six DGVMs driven by HadCM3 climate and four SRES scenarios - namely A1FI, A2, B1 and B2 - are $+5,4.5,5.4$ and $4.8 \%$, respectively (Sitch et al., 2008) (Table 4), while our simulated SOC increases using HadCM3 are +7.5, 3.5, 6.5 and 7.9\% (Table 5).

Müller et al. (2007) use the LPJmL model, driven by SRES scenarios A2, B1 and B2 and realisations of the AOGCMs HadCM2, ECHAM4, CGCM1 and CSIRO-MK1.2, to simulate changes of the land carbon balance during the 21 st century, while also considering land use change patterns derived from the IMAGE model. Simulations with the HadCM2 model and emission scenarios A2, B1 and B2 show an overall smaller increase of global SOC and even a decrease under A2 compared to our results (Table 5). This could be explained by the fact that the impact of land use change on SOC in their study includes the removal of harvested biomass and residue on arable land. Removal of harvested biomass and possibly residue is implicitly included in our simulations if a soil is under arable land use from the start of the simulation. However, if a soil undergoes a change from grassland or forest to arable, we only consider the impacts of changes in NPP and litter quality (see Sect. 2.6). We therefore might underestimate the loss of SOC when a soil changes from being under more or less natural land cover to a fully managed arable soil.

A compilation of simulation results of global SOC stock ranges in 2100 is presented in Table 4. Overall, the predicted variability of SOC stocks by the end of the 21 st century of our study ( $\pm 2-3 \%$ ) compares well with the results of Cramer et al. (2001), Ito (2005), Müller et al. (2007), Schaphoff et al. (2006) and Sitch et al. (2008) which range between $\pm 0.7-$ $4.4 \%$. Our study suggests that SOC stocks in 2100 show a slightly higher variability, due to using predictions from different AOGCMs interpreting one emission scenario (here A1b), rather than using one AOGCM interpreting a range of SRES scenarios. Respective results from Ito (2005) and Müller et al. (2007) suggest the opposite, with higher SOC stock variations in 2100 due to the variability among SRES 
scenarios interpreted by one AOGCM than due to the differences among AOGCMs interpreting one emission scenario. Interestingly, variability of SOC stocks by the end of the 21st century is much higher, if different biophysical models are driven by the same climate and emission scenario. The study of Sitch et al. (2008) predicts a spread in SOC values by 2099 of 21 and $22 \%$. Variability of simulated SOC stocks by 2100 by Friedlingstein et al. (2006) with 11 AOGCMs and each coupled with a different biophysical carbon-cycle model is even higher with $34 \%$. With the exception of the results by Cramer et al. (2001), this suggests that the variability in predictions of global SOC is higher due to the difference among the implementations of carbon-cycle dynamics than due to uncertainties in climate forcings and emission scenarios.

\subsection{Contribution of land use change to SOC stock changes}

Land use change occurs on $19 \%$ of the land area under the A1b scenario, and on $17 \%, 19 \%$ and $17 \%$ of the land under the B1, A2 and B2 scenarios, respectively. Simulations including the effects of climate, LUC and NPP together suggest LUCs from forest to arable constitute the largest SOC losses, while forest to grassland losses are negligible, in keeping with previous meta-analyses of LUC impacts on SOC (Guo and Gifford, 2002). All other types of LUC gain C, even grass to arable. This might constitute an artefact since our simulations do not include the negative impact of the removal of harvested biomass and residue. However, continuous arable soils seem to have the highest gain in organic $\mathrm{C}$ compared to grass and forest soils (Fig. 5), which might override losses due to biomass removal after land use change from grass to arable in the long term. Grassland to arable conversion is known to decrease SOC stocks (Guo and Gifford, 2002), but over the course of the simulations (130 years), increased NPP and/or decreased decomposition due to limiting soil moisture counteract these losses in some locations (Table 6), resulting in an overall global increase in mineral SOC despite the LUC-driven losses. Some grassland to arable conversions lose SOC and others gain, but due to NPP increases in some regions, the aggregate global change is a net increase in SOC. This net result would hold even if SOC losses due to the conversion of grass to arable were negative to the same extent as the SOC losses due to the conversion of forest to arable.

Figure 6 shows an assessment of the contribution of land use and NPP change to the projected SOC stock changes using HadCM3 with emission scenario A1b. Comparison of the simulation using fixed NPP in conjunction with changing land use, and the simulation that includes neither land use nor NPP change, shows that the impact of LUC on global SOC stocks is negligible. Figure 1 shows the distribution of simulated LUCs occurring from 1971 to 2100 . The simulation using fixed land use plus changing NPP shows that an NPP increase forced by climate change only would lead to a decrease in global SOC. The difference between the sim-

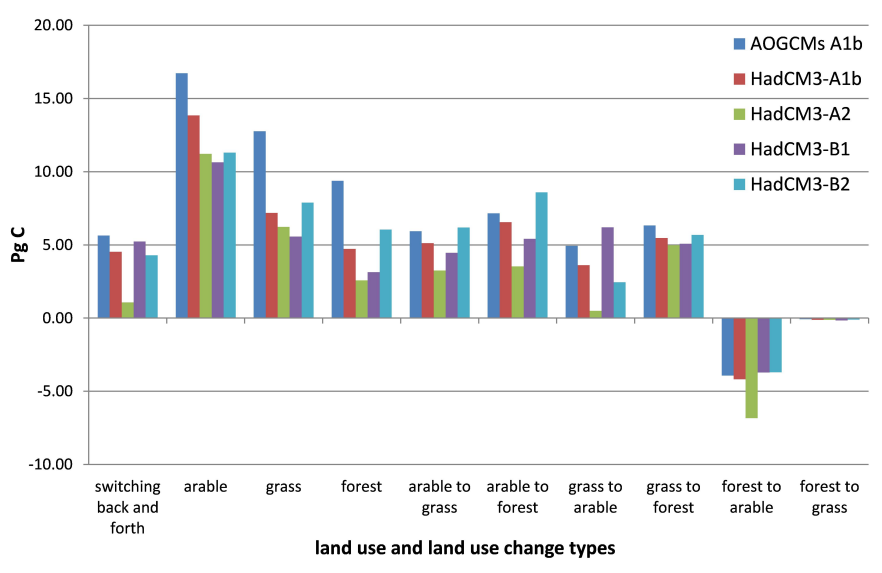

Fig. 5. Contribution of land use and land use change to global SOC stock changes (from 1971 to 2100).

ulation using fixed land-use plus NPP change and the default HadCM3 simulation approximately represents the effect of $\mathrm{CO}_{2}$-fertilisation. The increase in NPP due to $\mathrm{CO}_{2}-$ fertilisation could therefore be a dominant factor in determining whether SOC stocks continue to act as a sink of $\mathrm{C}$ in the future. This has also been shown for forest soils in Northeast China by Peng et al. (2009), who conducted a simulation with and without the $\mathrm{CO}_{2}$-fertilisation effect and showed a continuous loss of SOC from 2000 to 2100 without $\mathrm{CO}_{2}$ fertilisation, but an increase in forest $\mathrm{SOC}$ if $\mathrm{CO}_{2}$-fertilisation is included. Carbon losses were reduced by the $\mathrm{CO}_{2}$-fertilisation effect compared to the simulation without, in the study of Smith et al. (2009), for Canadian arable soils.

\subsection{Regional trends in SOC dynamics}

During the following discussion, environmental, SOC and plant input trends always refer to the average of all simulations, if not otherwise explicitly stated. Regions are as shown in Fig. 1.

Hotspots of SOC losses of more than $20 \mathrm{tCha}^{-1}$ are central and north-eastern Scandinavia, Northeast China and North and South Korea, a belt stretching from central China along its south-west border to northern India, the east coast of Canada and some small patches at Canada's south- west corner. Areas of medium SOC losses of less than $20 \mathrm{tC} \mathrm{ha}^{-1}$ cover the boreal zones of Northern and Eastern Europe, Eastern Canada and Alaska, mid- and northern India, central China and patchy regions in South America and southern Africa and Australia. Prominent SOC stock increases occur in east Brazil, while all remaining areas largely show a moderate increase from $0-20 \mathrm{tha}^{-1}$ up to $20-40 \mathrm{tha}^{-1}$ in smaller regions (Fig. 7). 


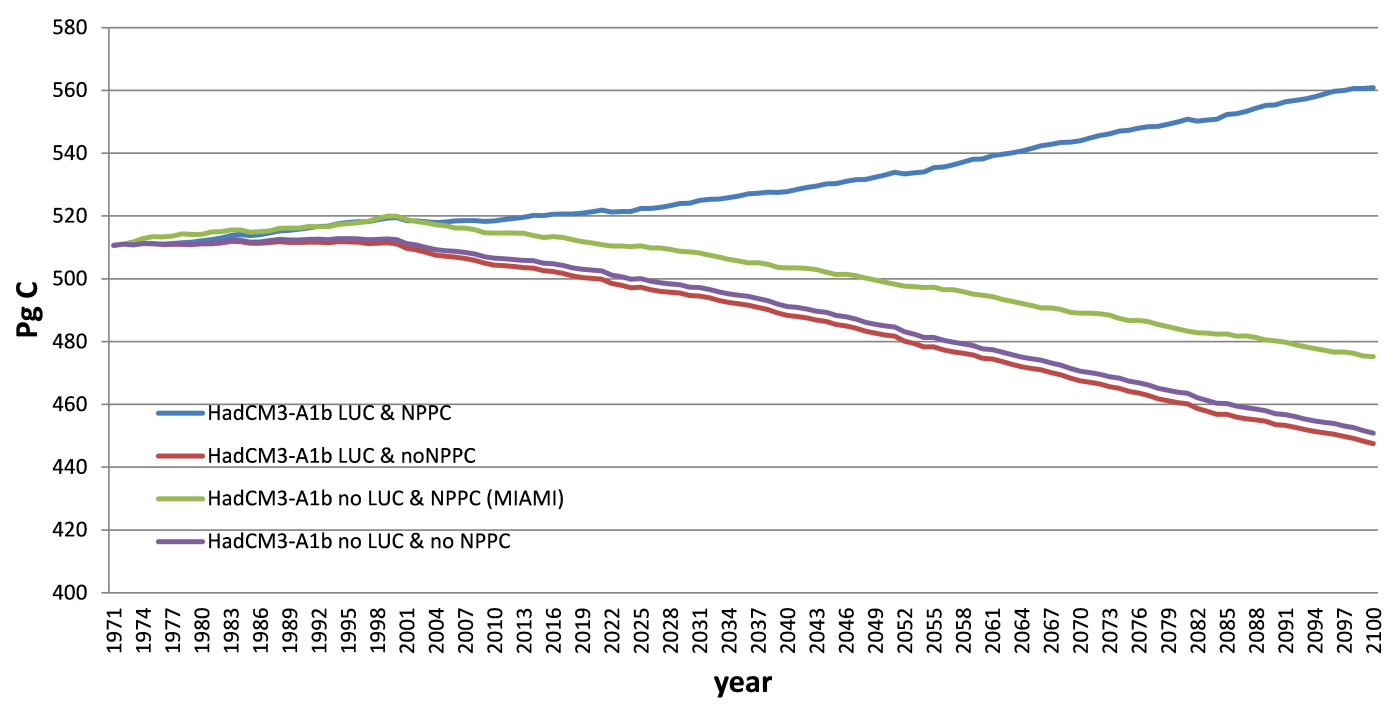

Fig. 6. Simulated changes in SOC stocks for four experimental set-ups using the climate scenario data of the HadCM 3 AOGCM in conjunction with A1b. Blue line: simulation including land use and NPP change; the latter is based on IMAGE NPP which includes the $\mathrm{CO}_{2}-$ fertilisation effect. Green line: simulation including no land use change but NPP change; the latter is based on temperature and precipitation changes only. Purple line: simulation including neither land use nor NPP change. Red line: simulation including land use change but no NPP change.

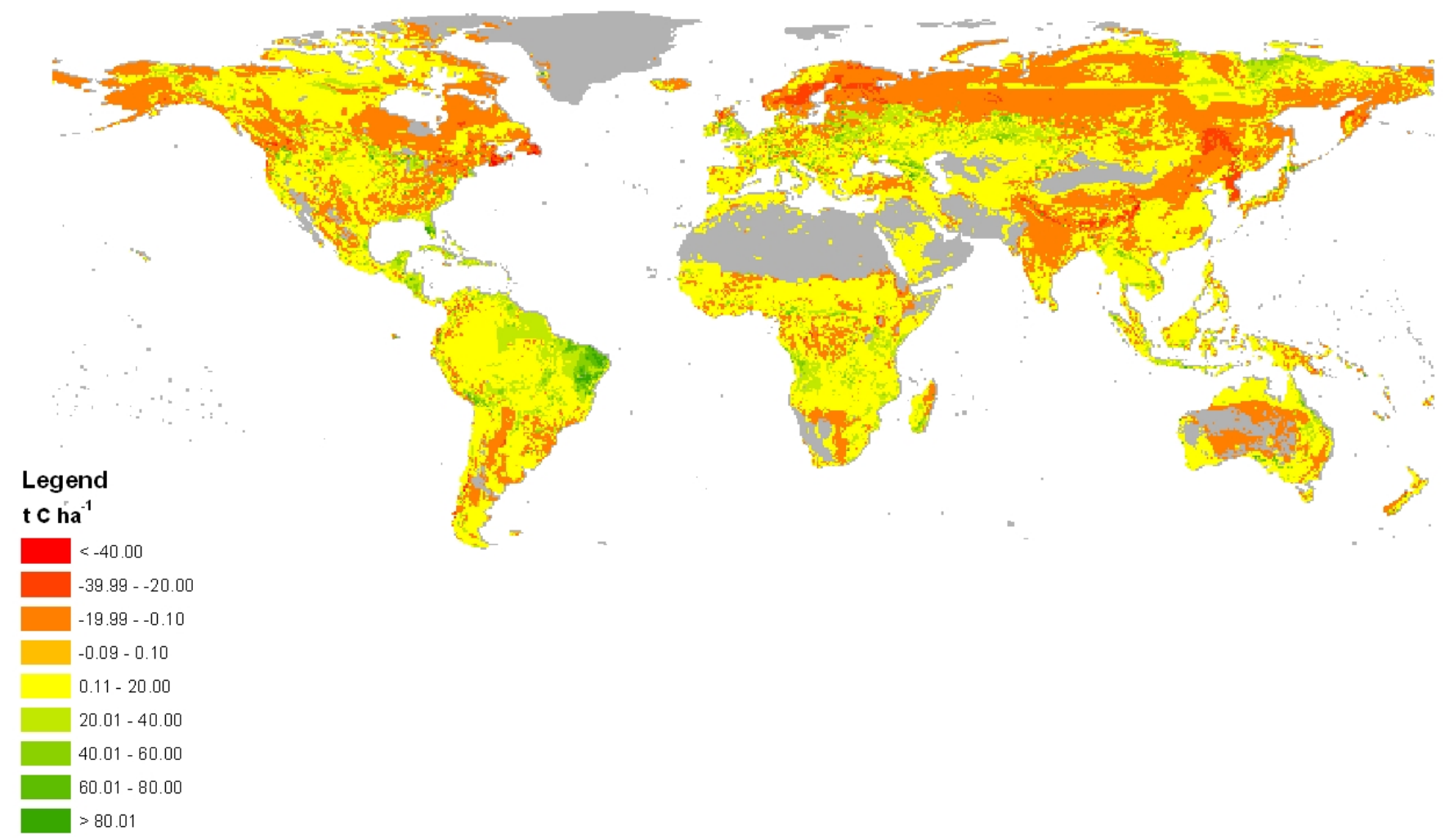

Fig. 7. Average trend in SOC concentration of all 10 scenarios from 1971 to 2100. 


\subsubsection{Northwest Pacific and East Asia (NW Pacific and E Asia) region}

Figure 8 and Table 6 show the relatively large impact of LUC on SOC stock for the NW Pacific and E Asia compared to the whole globe. About $25 \%$ (20\%-B1, 20\%-B2, $21 \%$-A2) of the area undergoes LUC, of which about $15 \%$ (15.5\%-B1, $9.7 \%-\mathrm{B} 2,10.5 \%-\mathrm{A} 2)$ is the conversion from grass to arable and about $9 \%(9 \%-\mathrm{B} 1,8.5 \%$-B2, $9 \%$-A2) is the conversion from forest to arable. The area as a whole shows the highest negative impact of LUC on SOC stocks compared to all other regions.

SOC losses in Northeast China and North and South Korea can be mainly attributed to LUC from forest to arable, while the belt of losses of SOC is due to changes from mainly grassland to arable conversions. Both changes are driven by decreasing plant inputs (Fig. 9).

The region as a whole shows a distinct SOC dynamic compared to other regions and the rest of the globe. While SOC trends of most regions show a continuous increase from 1971 to 2100, NW Pacific and E Asia show first a drop of SOC until ca. 2060 and thereafter a slight increase (Fig. 8). This pattern is caused by the $\mathrm{C}$ losses due to conversion to arable in the first part of the 21st century, which stabilises thereafter followed by a steady increase of arable SOC stocks during the 21 st century (data not shown). A very similar pattern has also been simulated for forests soils in Northeastern China by Peng et al. (2009). Peng et al. (2009) used a dedicated forest model (TRIPLEX 1.0) including the $\mathrm{CO}_{2}$ fertilisation effect on biomass production and climate scenario inputs from CGCM3.1 in conjunction with (among others) SRES A1. They also simulate a decrease in SOC levels from 2000 to ca. 2040 and thereafter a steady increase, but this is not due to LUC. No interpretation of these results is given. However, if we aggregate our results for continuous forest soils of the CGCM3.1 A1b simulation in NW Pacific and E Asia, we see a continuous loss of SOC. This difference to the study of Peng et al. (2009) is due to two factors (a) in the current study, plant inputs (i.e. NPP) remain fairly constant while Peng et al. (2009) simulate a continuous increase in biomass, and (b) in the current study, the temperature increase is stronger than in Peng et al. (2009) and hence plant inputs are driven by a lower temperature increase than in our CGCM3.1 A1b simulation (data not shown).

\subsubsection{Northern high latitudes, boreal forests and grasslands}

Under a warmer climate, soil organic matter decomposition increases if soil moisture is not limiting. These circumstances cause widespread SOC losses in Eurasia, Canada and Alaska as also shown by Schaphoff et al. (2006). These losses dominate the mean total mineral SOC response in the northern high latitudes (NHL), which is only slightly positive over the course of the simulation with an average increase over all simulations of $0.16 \%$. This is in contrast to Qian et al. (2010), who show a mean total SOC gain of $13 \%$ for the NHL of the $\mathrm{C}_{4}$ MIP-A2 simulations. In particular, the simulation with HadCM3LC results in a total SOC gain of $10 \%$, whereas our HadCM3-A2 simulation predicts a total loss of mineral SOC of $-3.1 \%$. This is however in agreement with the simulations of Jones et al. (2005) with HadCM3 and RothC, which predict a total SOC loss for the NHL of $-5 \%$. This suggests that mineral SOC dynamics as simulated with RothC is more sensitive to increasing temperatures in the northern latitudes than the SOC dynamic implementations of the $\mathrm{C}_{4}$ MIP models. Furthermore, Qian et al. (2010) explicitly point out that the "apparent "suppression" of warminginduced increase in SOM decomposition in the $\mathrm{C}_{4}$ MIP models still comes as somewhat of a surprise". Carbon losses in the area of Sweden are amplified due to the almost zero increase in plant inputs. However, central Canada's forests increase in SOC, because the temperature increase is more moderate and, although plant inputs are not higher than in the previously mentioned forest areas, they are large enough to counteract the SOC losses induced by higher temperature. The same applies to northern grasslands which generally gain SOC through temperature increases between 5 and $8{ }^{\circ} \mathrm{C}$. Soil organic $\mathrm{C}$ also increases under the northward shift of forests into grasslands. This is in agreement with simulation results using LPJ by Schaphoff et al. (2006), which predict an increase of SOC in central and Northern Canada.

The expansion of forest in conjunction with increased plant inputs in the area around Moscow triggers substantial SOC gains.

\subsubsection{Canada}

Canada exhibits small patches of high $\mathrm{C}$ loss of between 20 and $40 \mathrm{tha}^{-1}$ or even higher. These areas on the east coast are projected to undergo deforestation and conversion to arable, which is accompanied by decreased plant inputs, 4 to $6^{\circ} \mathrm{C}$ higher yearly average temperatures in 2100 than in 1971, and a lower water balance than in 1971. However, the arable region of Canada shows SOC gains of ca. $134 \mathrm{Tg}$ $\left(=4.9 \mathrm{tha}^{-1}\right)$ from 1971 to 2100 as the average value of all AOGCM simulations. The increase is due to slightly higher plant inputs, increased temperatures of 5 to $7^{\circ} \mathrm{C}$ and a lower water balance by 2100 . Our results are very similar to the results of the cropland climate-change study of Smith et al. (2009), which used climate change predictions from the IS92a emission scenario and SRES B2 driving the CGCM1 and CGCM2 model, respectively, in conjunction with the CENTURY model. They report SOC stocks under arable soils by 2099 of 2956 and $2742 \mathrm{TgC}$ respectively. Our equivalent value from using the CGCM3.1 model alone is $2752 \mathrm{Tg} \mathrm{C}$ for 2099 . This is equivalent to a SOC gain in arable soils from 1971 to 2100 of $229 \mathrm{Tg}$. 


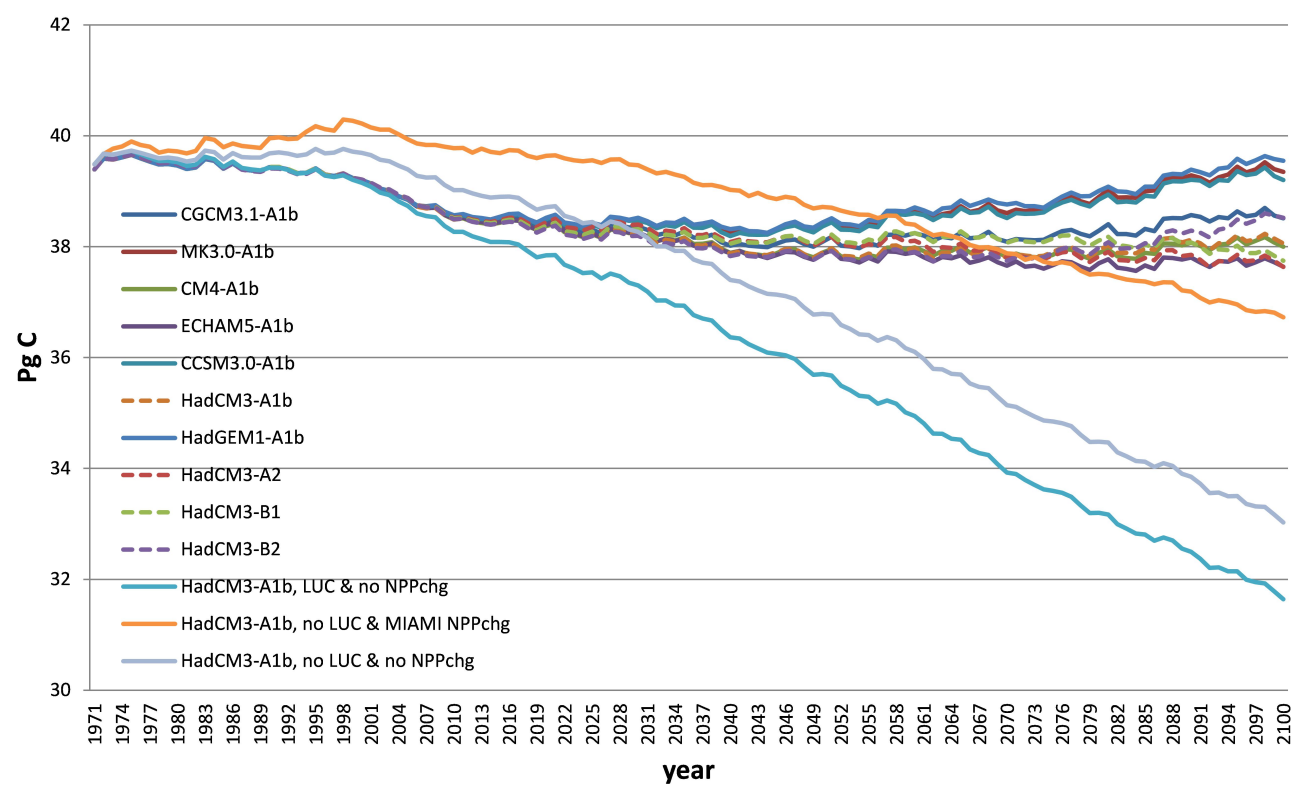

Fig. 8. Dynamic of total SOC changes aggregated over the region of NW Pacific and E Asia of all simulations (see text for further details).
Legend
$<-15.00$
$-14.99--10.00$
$-9.99--5.00$
$-4.99--0.10$
$-0.09-0.10$
$0.11-1.00$
$1.1-3.00$
$3.01-5.00$
$5.01-10.00$
$10.01-15.00$
$>15.01$

plant input change [t/ha]

Fig. 9. Average changes in plant inputs of all 10 scenarios. 
Table 6. Average SOC trend of seven GCMs per region and land use and land use change type.

\begin{tabular}{|c|c|c|c|c|c|c|c|c|c|c|}
\hline $\begin{array}{l}\text { average SOC trend } \\
\text { of } 7 \mathrm{GCMs} \mathrm{A} 1 \mathrm{~b}[\mathrm{Tg} \mathrm{C}]\end{array}$ & $\begin{array}{r}\text { switching } \\
\text { back and forth }\end{array}$ & arable & grass & forest & $\begin{array}{r}\text { arable } \\
\text { to grass }\end{array}$ & $\begin{array}{l}\text { arable } \\
\text { to forest }\end{array}$ & $\begin{array}{r}\text { grass } \\
\text { to arable }\end{array}$ & $\begin{array}{l}\text { grass } \\
\text { to forest }\end{array}$ & $\begin{array}{r}\text { forest } \\
\text { to arable }\end{array}$ & $\begin{array}{r}\text { forest } \\
\text { to grass }\end{array}$ \\
\hline North Africa & 23.50 & 513.07 & 422.28 & - & - & - & -25.81 & 98.08 & -8.64 & - \\
\hline Western Africa & 117.15 & 710.27 & 826.22 & 53.88 & 4.81 & - & 37.79 & 235.76 & -160.53 & - \\
\hline Central Africa & 506.54 & 548.26 & 288.74 & 1426.60 & - & - & 860.04 & 748.90 & -739.51 & - \\
\hline Eastern Africa & 43.15 & 1087.19 & 374.42 & -4.24 & - & - & 159.00 & 27.03 & -45.95 & - \\
\hline Western Indian Ocean & 0.00 & 492.44 & 37.83 & -7.03 & - & - & 225.21 & - & -99.34 & - \\
\hline Southern Africa & 88.94 & 2189.28 & 1163.00 & 3.46 & 82.45 & - & 2835.80 & 43.11 & 73.32 & - \\
\hline NW Pacific and East Asia & 33.76 & 1483.53 & -46.25 & -151.62 & 2.04 & 65.28 & -423.58 & 3.32 & -1708.21 & -35.36 \\
\hline Central Asia & 19.48 & 187.49 & 722.09 & -3.50 & 1784.80 & 73.28 & -6.71 & 21.07 & - & - \\
\hline Australia and New Zealand & 551.04 & 344.17 & 681.08 & -0.03 & 875.26 & & -11.53 & 34.30 & -16.54 & -14.38 \\
\hline South Pacific & 0.00 & 4.00 & - & 126.71 & - & 0.67 & - & 2.70 & -165.95 & \\
\hline Western Europe & 240.48 & 515.07 & 168.69 & -963.97 & 201.28 & 1101.84 & 1.68 & 90.94 & 3.03 & -14.67 \\
\hline Central Europe & 90.99 & 533.36 & 53.78 & 31.09 & 38.74 & 678.64 & -263.28 & 2.36 & -6.86 & -3.35 \\
\hline US & 318.12 & 837.05 & 446.88 & -546.72 & 1893.97 & 1573.90 & 44.46 & 310.14 & -5.88 & -14.99 \\
\hline Caribbean & 0.02 & 169.33 & 0.01 & 35.44 & - & - & 6.32 & 24.15 & 1.56 & \\
\hline Mesoamerica & 252.54 & 1203.11 & 171.27 & 501.10 & - & - & 222.98 & 12.17 & -6.68 & 12.13 \\
\hline Brazil & 1867.38 & 1776.55 & 3998.25 & 7172.83 & 88.37 & 237.69 & 645.00 & 1569.18 & -83.91 & 1.97 \\
\hline South America & 482.96 & 1873.73 & 1075.89 & 3159.57 & 36.77 & - & 532.32 & 545.51 & -386.58 & 15.59 \\
\hline
\end{tabular}

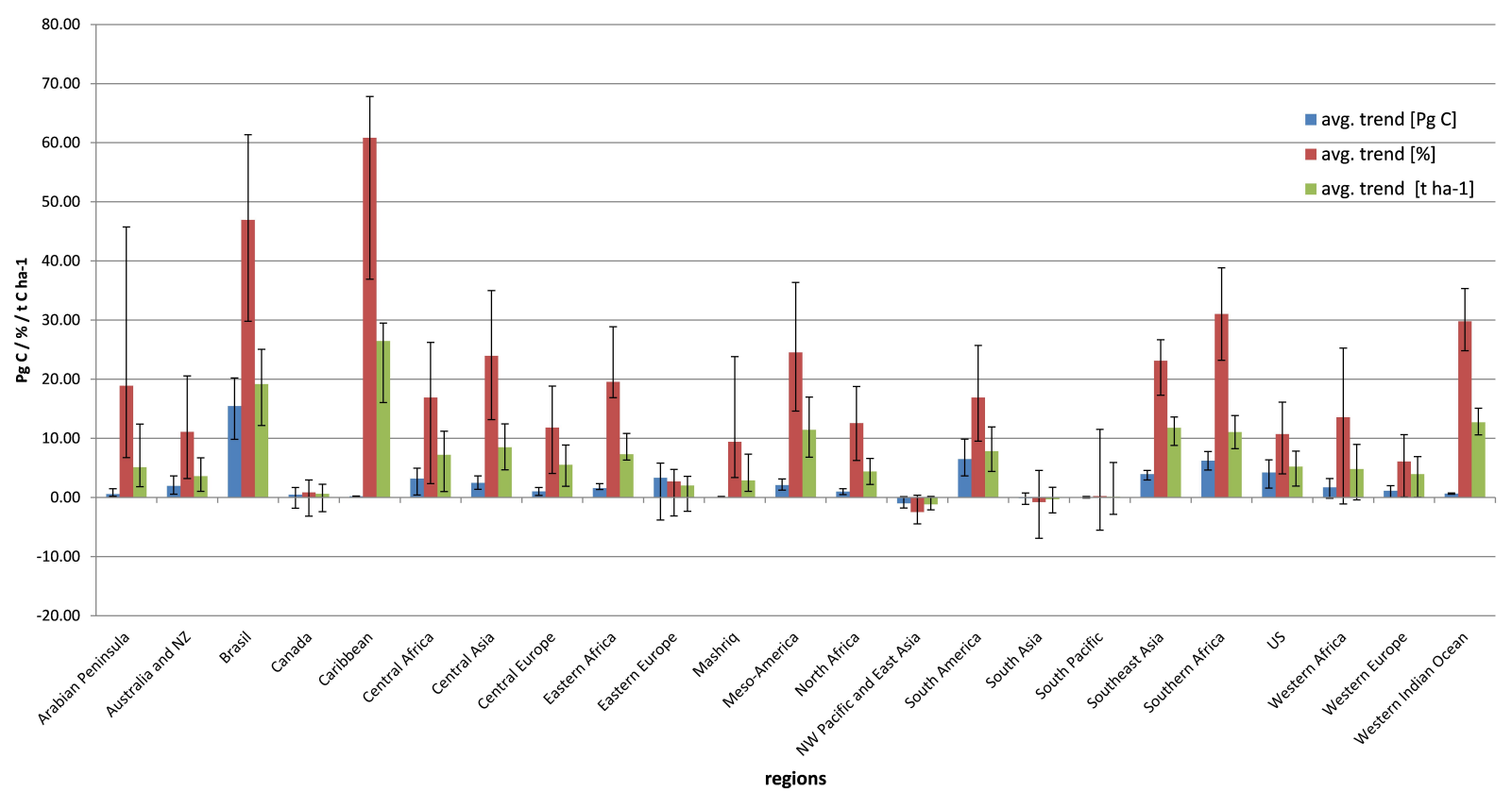

Fig. 10. Regional trends of average (of all scenarios) total SOC stocks, SOC concentrations and \% change and respective minimum and maximum values of all scenarios.

\subsubsection{USA}

Arable areas in central US and grassland areas in Western US areas profit from climate change in conjunction with increased plant inputs. However, the large forest areas situated in wetter parts of the future US lose SOC, despite generally increased plant inputs. This is in contrast to their Canadian counterparts, which show an increase in SOC, despite gaining less in plant inputs, due to a decreased rate of decomposition in the drier future soils. 


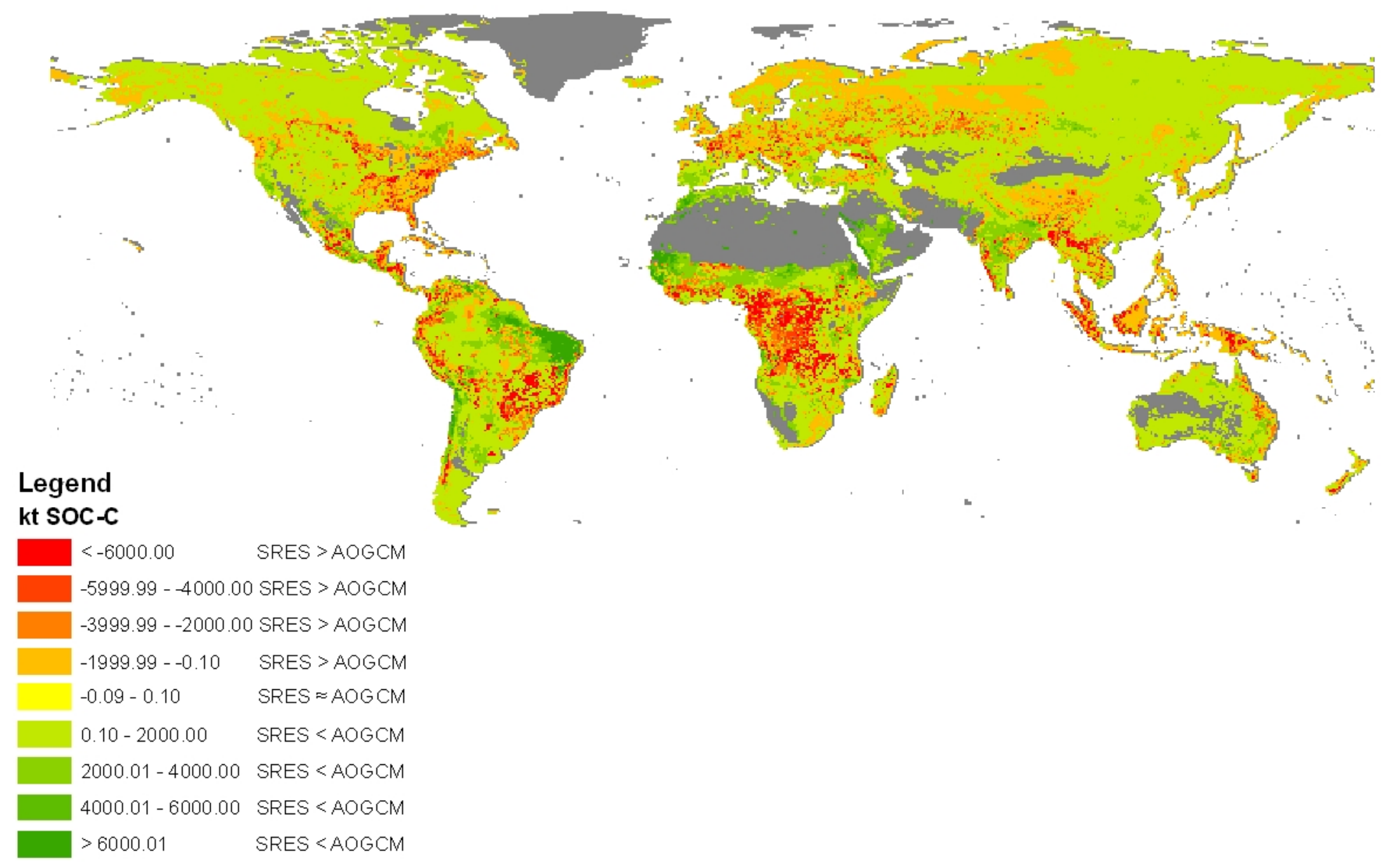

Fig. 11. Spatial distribution of the difference between the uncertainty in SOC stocks of AOGCM and SRES simulations. Uncertainty is calculated as the maximum spread between SOC results in 2100 among the AOGCM simulations and the SRES simulations respectively.

\subsubsection{South America and Brazil}

SOC stocks increase in most of South America and Brazil in the future, despite higher temperature of up to $+7-8^{\circ} \mathrm{C}$ in the centre of the continent. The water balance decreases in the north substantially, while some areas in middle and southern South America become much wetter than in 1971. Plant inputs increase on the whole continent and most prominently in eastern Brazil, where the highest SOC stock increases globally are found (Fig. 10). Only the lee side of the southern Andes shows a moderate decline in SOC, which correlates with increased plant inputs close to zero.

\subsubsection{Europe}

The whole of Europe shows moderate SOC gains. Moderately to highly increased plant inputs counteract enhanced SOM turnover under a warmer climate, where soil moisture is not a limiting factor. Hence, here these two processes tend to cancel each other out, as suggested by other studies for Western Europe (Smith et al., 2005, 2006).

\subsubsection{Africa}

Africa shows only two distinct areas of SOC losses. In central Africa, they are due to deforestation and conversion to arable in conjunction with hence lower plant inputs. In the south, SOC is lost due to increased soil organic matter decomposition under grassland, where the slightly increased plant inputs cannot counteract the losses. Arable soils and soils under grass to arable conversion profit from the overriding effect of increasing plant inputs over increased decomposition in the future. Also the simulations by Schaphoff et al. (2006) predict slight SOC gains in the Sahel zone due to a shift to C4 grasses support increasing NPP and dry conditions, and therefore limiting SOC turnover.

\subsubsection{India}

The SOC stocks of Indian soils, dominated by arable land use, will increase in the south but generally decrease in the centre and towards the north. This reflects the higher increases in plant inputs in the south and lesser increases northwards while most of the country becomes wetter and warmer, so increasing the rate of SOC decomposition. Overall, the SOC balance is predicted to be slightly positive under arable 

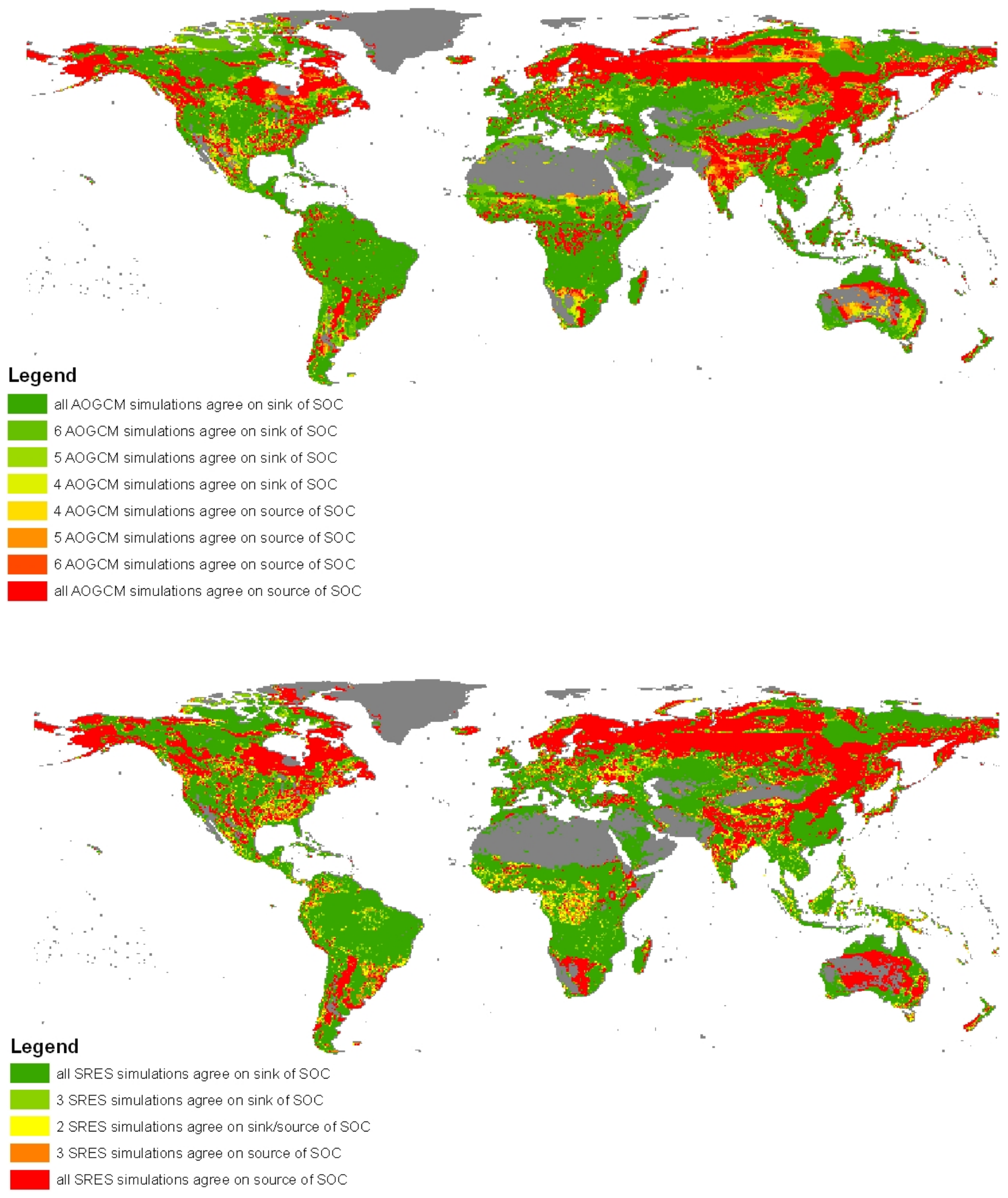

Fig. 12. Spatial distribution of areas where (a) the GCM simulation produces agreement on SOC becoming a source or a sink in 2100 when implemented in RothC, (b) SRES simulations with HadCM3 produce agreement on soils becoming a C source or a sink in 2100 when implemented in RothC. 
soils, because the local high increases in SOC are not outweighed by the widespread small losses.

\subsubsection{Australia}

Australia tends to lose SOC around its central desert area where grasslands are predicted to become drier and warmer in the future. The rate of SOC decomposition is slowed down under the drier conditions, and SOC stocks could increase here with a small increase in plant inputs. However, the temperature effect seems to outweigh the potential SOC gains. By contrast, the arable soils tend to increase in SOC due to the predicted increases in plant inputs. This is consistent with most other arable regions in our simulations.

\subsection{Consistency among simulations in predicting future SOC stocks}

The consistency among simulations shows considerable regional variation (Fig. 10). Regions such as the Arabian Peninsula, the Caribbean, central Africa and Mesoamerica have the highest local uncertainty in terms of how SOC concentrations develop in the future, but this uncertainty is not reflected in a global uncertainty, because these regions have a relatively small contribution to the total SOC stocks. By contrast, Brazil shows the third highest uncertainty in future changes in SOC concentration, but also the highest total SOC stock uncertainty, due to very high SOC gains. We can therefore distinguish between locally important uncertainties in the prediction of SOC stocks, which could impact people's livelihoods, and uncertainties which impact more on the global climate development. SOC predictions where soils become a source or sink in the future are highly uncertain in regions where some scenarios predict SOC losses and some scenarios predict SOC gains, such as in Canada, Eastern Europe, NW Pacific and E Asia, South Asia, South Pacific and Western Africa (Fig. 10).

Figure 11 shows the spatial distribution of the difference between the uncertainty of the AOGCM A1b simulations, and the HadCM3 SRES scenario simulations. The uncertainty is defined as the spread of SOC stock values of one set of simulations in 2100. A greater uncertainty in SOC between AOGCM runs than for the SRES predictions, for example in the Amazon region, reflects an inconsistency between the AOGCM climate projections. In these cases, the uncertainty in SOC introduced by different climate models is greater than the uncertainty introduced by GHG emission pathway scenarios.

Many of the simulations show agreement (Fig. 12) as to whether soils are predicted to act as a source or sink across climate models (a) and across SRES scenarios (b). The stronger the agreement between simulations, the higher is the probability that these results are robust with respect to the climate variable used to drive RothC. The maps do not, however, show the magnitude of SOC changes.

\section{Conclusions}

Globally, under a warming climate, increases are seen both in C inputs to the soil due to higher NPP, and in SOC losses due to increased decomposition (where soil moisture is not limiting). The balance between these processes defines the change in SOC stock. In some regions the processes balance, but in others, one process is affected by climate more than the other. This study suggests, with high probability, that in most parts of the world SOC stocks will change, with SOC losses projected to occur in northern latitudes where a higher SOC decomposition due to higher temperatures is not balanced by increased NPP, whereas in tropical regions, NPP increases override losses due to higher SOC decomposition. Pronounced regional trends are visible within this global picture. The spatial heterogeneity in the response of SOC to changing climate shows how delicately balanced the competing gain and loss processes are, with subtle changes in temperature, moisture, soil type and land use interacting to determine whether SOC increases or decreases in the future. Given this delicate balance, we should stop asking the general question of whether soils will increase or decrease in SOC under future climate, as there appears to be no single answer. Instead, we should focus our efforts on improving our prediction of factors that determine the size and direction of change, and the land management practices that can be implemented to protect and enhance SOC stocks as discussed in Smith (2008).

Acknowledgements. We thank the National Environment Research Council UK for funding this research through the QUEST-GSI Project. Pete Smith is a Royal Society-Wolfson Research Merit Award holder. This paper also contributes to the EU FP7-funded CCTAME, CarboExtreme and GHG-Europe projects, and to Scotland's ClimateXChange.

Edited by: J. Leifeld

\section{References}

Alcamo, J., Kreileman, G. J. J., Krol, M. S., and Zuidema, G.: Modeling the global society-biosphere-climate system: Part 1: Model description and testing, Water, Air, Soil Pollut., 76, 1-35, 1994.

Batjes, N. H.: ISRIC-WISE global data set of derived soil properties an a 0.5 by 0.5 degree grid (Version 3.0). Report 2005/08, ISRIC - World Soil Information, Wageningen (with data set), 2005.

Berthelot, M., Friedlingstein, P., Ciais, P., Dufresne, J.-L., and Monfray, P.: How uncertainties in future climate change predictions translate into future terrestrial carbon fluxes, Glob. Change Biol., 11, 959-970, 2005.

Cerri, C. E. P., Coleman, K., Jenkinson, D. S., Bernoux, M., Victoria, R., and Cerri, C. C.: Modeling Soil Carbon from Forest and Pasture Ecosystems of Amazon, Brazil, Soil Sci. Soc. Am. J., 67, 1879-1887, 2003. 
Coleman, K., Jenkinson, D. S., Crocker, G. J., Grace, P. R., Klir, J., Korschens, M., Poulton, P. R., and Richter, D. D.: Simulating trends in soil organic carbon in long-term experiments using RothC-26.3, Geoderma, 81, 29-44, 1997.

Coleman, K. W., and Jenkinson, D. S.: RothC-26.3 - A model for the turnover of carbon in soil., in: Evaluation of soil organic matter models using existing long-term datasets, edited by: Powlson, D. S., Smith, P., and Smith, J., NATO ASI Series I, Springer-Verlag, Heidelberg, 237-246, 1996.

Collins, W. D., Bitz, C. M., Blackmon, M. L., Bonan, G. B., Bretherton, C. S., Carton, J. A., Chang, P., Doney, S. C., Hack, J. J., Henderson, T. B., Kiehl, J. T., Large, W. G., McKenna, D. S., Santer, B. D., Smith, R. D.: The Community Climate System Model Version 3 (CCSM3), J. Clim., 19, 2122-2143, 2006.

Cox, P. M., Betts, R. A., Jones, C. D., Spall, S. A., and Totterdell, I. J.: Acceleration of global warming due to carbon-cycle feedbacks in a coupled climate model, Nature, 408, 184-187, 2000.

Cramer, W., Bondeau, A., Woodward, F. I., Prentice, I. C., Betts, R. A., Brovkin, V., Cox, P. M., Fisher, V., Foley, J. A., Friend, A. D., Kucharik, C., Lomas, M. R., Ramankutty, N., Sitch, S., Smith, B., White, A., and Young-Molling, C.: Global response of terrestrial ecosystem structure and function to $\mathrm{CO}_{2}$ and climate change: results from six dynamic global vegetation models, Glob. Change Biol., 7, 357-373, 2001.

Davidson, E. A. and Janssens, I. A.: Temperature sensitivity of soil carbon decomposition and feedbacks to climate change, Nature, 440, 165-173, 2006.

Diels, J., Vanlauwe, B., Van der Meersch, M. K., Sanginga, N., and Merckx, R.: Long-term soil organic carbon dynamics in a subhumid tropical climate: $13 \mathrm{C}$ data in mixed $\mathrm{C} 3 / \mathrm{C} 4$ cropping and modeling with ROTHC, Soil Biol. Biochem., 36, 1739-1750, 2004.

Dufresne, J. L., Fairhead, L., Le Treut, H., Berthelot, M., Bopp, L., Ciais, P., Friedlingstein, P., and Monfray, P.: On the magnitude of positive feedback between future climate change and the carbon cycle, Geophys. Res. Lett., 29, 1405, 2002.

Eglin, T., Ciais, P., Piao, S. L., Barre, P., Bellassen, V., Cadule, P., Chenu, C., Gasser, T., Koven, C., Reichstein, M., and Smith, P.: Historical and future perspectives of global soil carbon response to climate and land-use changes, Tellus B, 62, 700-718, 2010.

Falloon, P., and Smith, P.: Simulating SOC changes in long-term experiments with RothC and CENTURY: model evaluation for a regional scale application, Soil Use Manage., 18, 101-111, doi:10.1111/j.1475-2743.2002.tb00227.x, 2002.

Falloon, P. D., Smith, P., Smith, J. U., Szabó, J., Coleman, K., and Marshall, S.: Regional estimates of carbon sequestration potential: linking the Rothamsted Carbon Model to GIS databases, Biol. Fertil. Soils, 27, 236-241, 1998.

Fang, C., Smith, P., Moncrieff, J. B., and Smith, J. U.: Similar response of labile and resistant soil organic matter pools to changes in temperature, Nature, 433, 57-59, 2005.

Friedlingstein, P., Dufresne, J. L., Cox, P. M., and Rayner, P.: How positive is the feedback between climate change and the carbon cycle?, Tellus B, 55, 692-700, 2003.

Friedlingstein, P., Cox, P., Betts, R., Bopp, L., von Bloh, W., Brovkin, V., Cadule, P., Doney, S., Eby, M., Fung, I., Bala, G., John, J., Jones, C., Joos, F., Kato, T., Kawamiya, M., Knorr, W., Lindsay, K., Matthews, H. D., Raddatz, T., Rayner, P., Reick, C., Roeckner, E., Schnitzler, K. G., Schnur, R., Strassmann,
K., Weaver, A. J., Yoshikawa, C., and Zeng, N.: Climate-Carbon Cycle Feedback Analysis: Results from the $\mathrm{C}_{4} \mathrm{MIP}$ Model Intercomparison, J. Clim., 19, 3337-3353, doi:10.1175/JCLI3800.1, 2006.

Giorgetta, M.A., Brasseur, G.P., Roeckner, E., Marotzke, J.: Preface to Special Section on Climate Models at the Max Planck Institute for Meteorology, J. Clim. 19, 3769-3770, 2006.

Gordon, C., Cooper, C., Senior, C. A., Banks, H., Gregory, J. M., Johns, T. C., Mitchell, J. F. B., and Wood, R. A.: The simulation of SST, sea ice extents and ocean heat transports in a version of the Hadley Centre coupled model without flux adjustments, Clim. Dynam., 16, 147-168, 2000.

Gordon, H. B., Rotstayn, L. D., McGregor, J. L., Dix, M. R., Koalczyk, E. A., O'Farrell, S. P., Waterman, L. J., Hirst, A. C., Wilson, S. G., Collier, M. A., Watterson, I. G., and Elliott, T. I.: The CSIRO Mk3 Climate System Model [Electronic publication]. Aspendale: CSIRO Atmospheric Research, Technical paper no. 60, 130 pp., 2002.

Guo, L. B. and Gifford, R. M.: Soil carbon stocks and land use change: a meta analysis, Glob. Change Biol., 8, 345-360, doi:10.1046/j.1354-1013.2002.00486.x, 2002.

Hourdin, F., Musat, I., Bony, S., Braconnot, P., Codron, F., Dufresne, J.-L., Fairhead, L., Filiberti, M.-A., Friedlingstein, P., Grandpeix, J.-Y., Krinner, G., LeVan, P., Li, Z.-X., Lott, F.: The LMDZ4 general circulation model: climate performance and sensitivity to parametrized physics with emphasis on tropical convection, Clim. Dynam., 27, 787-813, 2006.

Ito, A.: Climate-related uncertainties in projections of the twentyfirst century terrestrial carbon budget: off-line model experiments using IPCC greenhouse-gas scenarios and AOGCM climate projections, Clim. Dynam., 24, 435-448, 2005.

Jenkinson, D. S., Adams, D. E., and Wild, A.: Model estimates of $\mathrm{CO}_{2}$ emissions from soil in response to global warming, Nature, 351, 304-306, 1991.

Jenkinson, D. S., Harris, H. C., Ryan, J., McNeill, A. M., Pilbeam, C. J., and Coleman, K.: Organic matter turnover in a calcareous clay soil from Syria under a two-course cereal rotation, Soil Biol. Biochem., 31, 687-693, 1999.

Jobbagy, E. G. and Jackson, R. B.: The Vertical Distribution of Soil Organic Carbon and Its Relation to Climate and Vegetation, Ecol. Appl., 10, 423-436, 2000.

Johns, T. C., Durman, C. F., Banks, H. T., Roberts, M. J., McLaren, A. J., Ridley, J. K., Senior, C. A., Williams, K. D., Jones, A., Rickard, G. J., Cusack, S., Ingram, W. J., Crucifix, M., Sexton, D. M. H., Joshi, M. M., Dong, B. W., Spencer, H., Hill, R. S. R., Gregory, J.M., Keen, A. B., Pardaens, A. K., Lowe, J.A., BodasSalcedo, A., Stark, S., Searl, Y.: The New Hadley Centre Climate Model (HadGEM1): Evaluation of Coupled Simulations, J. Clim., 19, 1327-1353, 2006.

Jones, C., McConnell, C., Coleman, K., Cox, P., Falloon, P., Jenkinson, D., and Powlson, D.: Global climate change and soil carbon stocks; predictions from two contrasting models for the turnover of organic carbon in soil, Glob. Change Biol., 11, 154-166, doi:10.1111/j.1365-2486.2004.00885.x, 2005.

Joosten, H.: The IMCG global peatland database. International Mire Conservation Group, available at: www.imcg.net/gpd/gpd.htm, 2009. 
Kamoni, P. T., Gicheru, P. T., Wokabi, S. M., Easter, M., Milne, E., Coleman, K., Falloon, P., Paustian, K., Killian, K., and Kihanda, F. M.: Evaluation of two soil carbon models using two Kenyan long term experimental datasets, Agr. Ecosyst. Environ., 122, 95-104, 2007.

Klein Goldewijk, K., Minnen, J. G., Kreileman, G. J. J., Vloedbeld, M., and Leemans, R.: Simulating the carbon flux between the terrestrial environment and the atmosphere, Water, Air, Soil Pollut., 76, 199-230, 1994.

Knorr, W., Prentice, I. C., House, J. I., and Holland, E. A.: Longterm sensitivity of soil carbon turnover to warming, Nature, 433, 298-301, 2005.

Lal, R.: Soil erosion and the global carbon budget, Environ. Int., 29, 437-450, doi:10.1016/s0160-4120(02)00192-7, 2003.

Lal, R.: Soil carbon sequestration impacts on global climate change and food security, Science, 304, 1623-1627, 2004.

Lieth, H.: The primary productivity of the world, Nature and Resources UNESCO, VIII, 5-10, 1972.

Lieth, H.: Modelling the primary productivity of the world, in: Primary productivity of the Biosphere, edited by: Lieth, H., and Whittaker, R. H., Springer-Verlag, New York, 237-263, 1975.

Lucht, W., Schaphoff, S., Erbrecht, T., Heyder, U., Cramer, W.: Terrestrial vegetation redistribution and carbon balance under climate change, Carbon Balance and Management, p. 7, 2006.

McFarlane, N. A., Scinocca, J. F., Lazare, M., Harvey, R. Verseghy, D., Li, J.: The CCCma third generation atmospheric general circulation model. CCCma Internal Report, 25 pp, 2005.

McGill, W. B.: Review and classification of 10 soil organic matter (SOM) models, in: Evaluation of Soil Organic Matter models Using Long-Term Datasets, NATO ASI Series I, edited by: Powlson, D. S., Smith, P., and Smith, J., Springer-Verlag, Heidelberg, Germany, 111-132, 1996.

MNP: Integrated modelling of global environmental change. An overview of IMAGE 2.4, edited by: Bouwman, A. F., Kram, T., and Klein Goldewijk, K., Netherlands Environmental Assessment Agency (MNP), Bilthoven, The Netherlands, 2006.

Müller, C., Eickhout, B., Zaehle, S., Bondeau, A., Cramer, W., and Lucht, W.: Effects of changes in $\mathrm{CO}_{2}$, climate, and land use on the carbon balance of the land biosphere during the 21 st century, J. Geophys. Res., 112, G02032, doi:10.1029/2006jg000388, 2007.

Peng, C., Zhou, X., Zhao, S., Wang, X., Zhu, B., Piao, S., Fang, J.: Quantifying the response of forest carbon balance to future climate change in Northeastern China: Model validation and prediction, Global Planet. Change 66, 179-194, 2009.

Post, W. M., Emanuel, W. R., Zinke, P. J., and Stangenberger, A. G.: Soil carbon pools and world life zones, Nature, 298, 156$159,1982$.

Qian, H., Joseph, R., and Zeng, N.: Enhanced terrestrial carbon uptake in the Northern High Latitudes in the 21st century from the Coupled Carbon Cycle Climate Model Intercomparison Project model projections, Glob. Change Biol., 16, 641-656, doi:10.1111/j.1365-2486.2009.01989.x, 2010.

Schaphoff, S., Lucht, W., Gerten, D., Sitch, S., Cramer, W., and Prentice, I.: Terrestrial biosphere carbon storage under alternative climate projections, Clim. Change, 74, 97-122, 2006.

Scinocca, J. F., McFarlane, N. A., Lazare, M., Li, J., and Plummer, D.: Technical Note: The CCCma third generation AGCM and its extension into the middle atmosphere, Atmos. Chem. Phys., 8,
7055-7074, doi:10.5194/acp-8-7055-2008, 2008.

Shirato, Y., Paisancharoen, K., Sangtong, P., Nakviro, C., Yokozawa, M., and Matsumoto, N.: Testing the Rothamsted Carbon Model against data from long-term experiments on upland soils in Thailand, Europ. J. Soil Sci., 56, 179-188, doi:10.1111/j.1365-2389.2004.00659.x, 2005.

Sitch, S., Huntingford, C., Gedney, N., Levy, P. E., Lomas, M., Piao, S. L., Betts, R., Ciais, P., Cox, P., Friedlingstein, P., Jones, C. D., Prentice, I. C., and Woodward, F. I.: Evaluation of the terrestrial carbon cycle, future plant geography and climate-carbon cycle feedbacks using five Dynamic Global Vegetation Models (DGVMs), Glob. Change Biol., 14, 2015-2039, doi:10.1111/j.1365-2486.2008.01626.x, 2008.

Skjemstad, J. O., Spouncer, L. R., Cowie, B., and Swift, R. S.: Calibration of the Rothamsted organic carbon turnover model (RothC ver. 26.3), using measurable organic carbon pools, Austr. J. Soil Res., 42, 79-88, 2004.

Smith, J., Smith, P., Wattenbach, M., Zaehle, S., Hiederer, R., Jones, R. J. A., Montanarella, L., Rounsevell, M. D. A., Reginster, I., and Ewert, F.: Projected changes in mineral soil carbon of European croplands and grasslands, 1990-2080, Glob. Change Biol., 11, 2141-2152, 2005.

Smith, P., Smith, J. U., Powlson, D. S., Coleman, K., Jenkinson, D. S., McGill, W. B., Arah, J. R. M., Thornley, J. H. M., Chertov, O. G., Komarov, A. S., Franko, U., Frolking, S., Li, C., Jensen, L. S., Mueller, T., Kelly, R. H., Parton, W. J., Klein-Gunnewiek, H., Whitmore, A. P., and Molina, J. A. E.: A comparison of the performance of nine soil organic matter models using datasets from seven long-term experiments, Geoderma, 81, 153-225, 1997.

Smith, P.: Carbon sequestration in croplands: the potential in Europe and the global context, Eur. J. Agron., 20, 229-236, 2004.

Smith, P., Smith, J., Wattenbach, M., Meyer, J., Lindner, M., Zaehle, S., Hiederer, R., Jones, R. J. A., Montanarella, L., Rounsevell, M., Reginster, I., and Kankaanpää, S.: Projected changes in mineral soil carbon of European forests, 1990-2100, Canad. J. Soil Sci., 86, 159-169, 2006.

Smith, P., Smith, J. U., Franko, U., Kuka, K., Romanenkov, V. A., Shevtsova, L. K., Wattenbach, M., Gottschalk, P., Sirotenko, O. D., Rukhovich, D. I., Koroleva, P. V., Romanenko, I. A., and Lisovoi, N. V.: Changes in soil organic carbon stocks in the croplands of European Russia and the Ukraine, 1990-2070; comparison of three models and implications for climate mitigation, Reg. Environ. Change, 7, 105-119, doi:10.1007/s10113-007-0028-2, 2007.

Smith, P.: Land use change and soil organic carbon dynamics, Nutr. Cycl. Agroecosys., 81, 169-178, 2008.

Smith, P., Fang, C., Dawson, J. J. C., Moncrieff, J. B., and Donald, L. S.: Impact of Global Warming on Soil Organic Carbon, Adv. Agron., 97, 1-43, 2008.

Smith, W., Grant, B., Desjardins, R., Qian, B., Hutchinson, J., and Gameda, S.: Potential impact of climate change on carbon in agricultural soils in Canada 2000-2099, Climatic Change, 93, 319-333, 2009.

Tate, K. R., Scott, N. A., Parshotam, A., Brown, L., Wilde, R. H., Giltrap, D. J., Trustrum, N. A., Gomez, B., and Ross, D. J.: A multi-scale analysis of a terrestrial carbon budget: Is New Zealand a source or sink of carbon?, Agr. Ecosyst. Environ., 82, 229-246, 2000. 
Van Minnen, J., Klein Goldewijk, K., Stehfest, E., Eickhout, B., van Drecht, G., and Leemans, R.: The importance of three centuries of land-use change for the global and regional terrestrial carbon cycle, Climatic Change, 97, 123-144, 2009.

Van Minnen, J. G., Leemans, R., and Ihle, F.: Defining the importance of including transient ecosystem responses to simulate Ccycle dynamics in a global change model, Glob. Change Biol., 6, 595-611, 2000.
Wang, Y. P., and Polglase, P. J.: Carbon balance in the tundra, boreal forest and humid tropical forest during climate change: scaling up from leaf physiology and soil carbon dynamics, Plant, Cell Environ., 18, 1226-1244, 1995.

Zheng, D. L., Prince, S., and Wright, R.: Terrestrial net primary production estimates for 0.5 degrees grid cells from field observations - a contribution to global biogeochemical modelling, Glob. Change Biol., 9, 46-64, 2003. 